\title{
Design and study of a pure tire pyrolysis oil (TPO) and blended with Brazilian diesel using Y-Jet atomizer
}

\author{
German R. A. Chumpitaz ${ }^{1}$. Christian J. R. Coronado ${ }^{1}$ • João A. Carvalho Jr. ${ }^{2} \cdot J^{\prime}$ osé C. Andrade ${ }^{3}$. \\ Andrés Z. Mendiburu ${ }^{2} \cdot$ Gabriel M. Pinto $^{1} \cdot$ Túlio A. de Souza $^{1}$
}

Received: 12 April 2018 / Accepted: 8 February 2019

(c) The Brazilian Society of Mechanical Sciences and Engineering 2019

\begin{abstract}
This manuscript aims to study the atomization and characterization of tire pyrolysis oil (TPO); thus, Y-Jet atomizers have been designed and manufactured by using an experimental bench, which was specifically built for such a purpose. The droplet size was measured experimentally and compared with the theoretical value obtained with the equation proposed by Wigg. The potential for production of TPO in Brazil from tires discarded for 2016 was approximately 190 million liters and in the world for the same year was 4160 million liters; these values represent an excellent alternative for the energetic use of these oils as well as a good way to valorize the by-products obtained from tire pyrolysis such as char and tire gas. The TPO can be used in combustion processes in pure form or mixed with other renewable or non-renewable fuels, so it is important to study atomization processes that guarantee an excellent quality of combustion. The spray quality generated by atomizing pure TPO and in blends (TPO-diesel) has been quantified by droplet size measurement through the Spraytec Malvern 2007 laser diffraction system, whose main properties have also been measured, such as density, viscosity and surface tension of pure liquid fuels and blends, liquid and gas flow pressure at the atomizer nozzle, and droplet size distributions generated by the atomized jet for different gas/liquid ratio values. The influence of the point where liquid pressure exceeds gas pressure at the atomizer nozzle, as well as the TPO percentage effect on droplet size, is demonstrated, and a comparison of experimental droplet size with the one which had been theoretically calculated by Wigg's equation is made. The study of the atomization of TPO, pure and blends, allows to know a favorable condition for its burning and provides a suitable destination for discarded tires. For a better characterization of the spray, the atomization cone angle was also measured for all the mixtures.
\end{abstract}

Keywords Nozzle $\cdot$ Atomization $\cdot$ Tire $\cdot$ Pyrolysis $\cdot$ Compressible fluid

$\begin{array}{ll}\text { List of symbols } \\ H & \text { Blending chamber radius }(\mathrm{cm}) \\ k & \text { Isentropic coefficient } \\ \dot{m} & \text { Mass flow }(\mathrm{kg} / \mathrm{s}) \\ M & \text { Mach number }\end{array}$

Technical Editor: Fernando Marcelo Pereira, PhD.

Christian J. R. Coronado

christian@unifei.edu.br

1 Mechanical Engineering Institute - IEM, Federal University of Itajubá - UNIFEI, BPS Ave. 1303, Itajubá, MG CEP 37500-903, Brazil

2 Campus of Guaratinguetá - FEG, São Paulo State University - UNESP, Ariberto P. da Cunha Ave. 333, Guaratinguetá, SP CEP 12510410, Brazil

3 Combustion and Propulsion Laboratory - LCP, National Space Research Institute - INPE, Rod. Pres. Dutra, km 39, Cachoeira Paulista, SP CEP 12630-000, Brazil

$\begin{array}{ll}P & \text { Pressure }(\mathrm{Pa}) \\ R & \text { Universal gas constant }(\mathrm{kJ} / \mathrm{kmol} \mathrm{K}) \\ T & \text { Temperature }(\mathrm{K}) \\ U & \text { Atomizing air speed }(\mathrm{m} / \mathrm{s}) \\ \rho & \text { Density }\left(\mathrm{g} / \mathrm{cm}^{3}\right) \\ \sigma & \text { Surface tension }(\mathrm{N} / \mathrm{m}) \\ v & \text { Kinematic viscosity }(\mathrm{cSt}) \\ \text { PCI } & \text { Lower heating value }(\mathrm{kJ} / \mathrm{kg}) \\ \text { PCS } & \text { Upper heating value }(\mathrm{kJ} / \mathrm{kg}) \\ \text { DMMD } & \text { Mass median diameter }(\mu \mathrm{m}) \\ \text { DSMD } & \text { Sauter mean diameter, D32 }(\mu \mathrm{m}) \\ \text { GLR } & \text { Gas/liquid }(\text { mass }) \text { ratio } \\ \text { TPO } & \text { Tire pyrolysis oil } \\ \text { Petrobras } & \text { Brazilian State Oil Company }\end{array}$

Superscripts and subscripts

$0 \quad$ Stagnation conditions

* $\quad$ Critical properties $(\mathrm{Ma}=1)$ 
A

$L$

Atomizing air

Liquid

\section{Introduction}

The amount of tires that has been currently produced is an environmental problem due to the quantity of tire disposal worldwide year-round. Thus, many countries have established legal standards to supervise all that refers to the process of waste final disposal aimed at reusing by mechanical or thermochemical means.

This was due to the difficulty in the final treatment of these wastes, and thus, there are a few ways to properly dispose of tires in Brazil, e.g., manufacture of rubber elements, co-processing in the cement industry, asphalt production and as an alternative energy source by direct burning or through a thermochemical treatment to generate a new kind of fuel (tire pyrolysis oil-TPO), in which it is possible to generate energy through its combustion process. In terms of combustion, it is known that an excellent atomization of liquid fuels improves the process; therefore, this work aims to create the conditions for a good atomization of a non-traditional fuel (TPO) that can be used for energy purposes, pure or blends.

Brazil discards 510,449.83 $\mathrm{t}$ of tires per year, of which $96.66 \%$ are collected for a correct final destination; of this amount, 297,168.8 $\mathrm{t}$ are used energetically in co-processing processes and $5344.49 \mathrm{t}$ in pyrolysis processes [1]. According to Galvagno et al. [42] in a pyrolysis process, approximately $34 \%$ are for liquid fraction (TPO), $49 \%$ char, $7 \%$ gas and $10 \%$ losses. If the final destination goal is reached in Brazil (100\% of the tires that enter the aftermarket) and all tires are taken to a correct final destination in a pyrolysis process, the amount of TPO generated would be approximately 190 million liters annually. On the other hand, at the global level, if all the tires that were produced in 2016 were converted to TPO by pyrolysis processes, the amount of TPO generated would be 4161 million liters per year [2]. The main products of tire pyrolysis are char, pyrolysis gas and TPO, the char is used in the production of activated carbon filters and can also be used as an additive in the asphalt industry, rubber and mixed with bitumen [3], and finally, the pyrolysis gas can be used as a fuel in the pyrolysis process [8].

The purpose of this work is to use TPO in direct burning in combustion chambers in a pure form or blended with conventional liquid fossil fuels using atomizers specially designed and built for TPO.

In the scientific literature, there are some published works on the combustion of TPO and blends with fossil diesel and biodiesel in internal combustion engines, and in all cases, the study and design of the atomizers were not approached [3-21]. Regarding the amount of sulfur present in the TPO, even though it presents similar amounts to other fossil fuels $[3,5]$, this content is higher than diesel, so in some cases the TPO desulfurization procedures are used $[4,5,7,18]$. The TPO used in this study did not have prior desulfurization treatment, which is why it presented a higher amount of sulfur in its composition.

In the studies found in the literature and presented in Table 1, the tests carried out on internal combustion engines showed different effects related to the use of diesel mixtures with TPO, generally with thermal yields lower than diesel only, influenced mainly by the decrease in the power with the increase in the amount of TPO in the mixture [22], so it was also possible to observe an increase in the amount of pollutants produced in relation to diesel.

In the field research, the use of pure TPO and in blends with diesel in internal combustion engines is reported in large numbers and in a small number if it is used with other types of thermal machines. The studies show that adding TPO to diesel generally represents a small decrease in performance and an increase in some pollutants, but there is no marked difference in both cases, except in the amount of sulfur derivatives produced, which is why some studies focus their work on previous processes of desulfurization.

In addition to the blends with diesel, Sharma and Murugan used blends with biodiesel produced from Jatropha seed oil by the transesterification process, in order to take advantage of its high cetane number to improve the properties of the blend.

The research mentioned previously in Table 1 focuses on the study of the substitution of fuels, without deepening the variations inherent in the atomization process, which is very important in the combustion process. It is for this reason that this study analyzes the effects of the use of diesel mixtures with TPO on the quality of the spray generated, by measuring the droplet size and atomization cone angle.

The atomizers used in this work were specially designed, constructed and tested to be used with TPO; later, these atomizers were also used with diesel/TPO blends. Table 1 summarizes the scientific literature in this field.

In short, the present work presents the experimental study of TPO atomization, using a low-power Y-Jet injector. In the experimental tests carried out herein, a twin-fluid Y-Jet atomizer has been designed, built and tested for different liquid fuel blends by experimental bench for atomization studies, which has also been specially created and built for such a purpose. The characterization of the atomization was performed with the experimental measurement of the droplet size on the built bench and then compared with the theoretical model that will be discussed in detail in the next sections. 
Table 1 Review of studies of blends of TPO with other fuels

\begin{tabular}{lll}
\hline Authors (year) & Liquid & Device \\
\hline Williams et al. [3] & TPO and diesel & Furnace \\
& & \\
Murugan et al. [4] & DTPO (distilled tire pyrolysis oil) and diesel & Diesel engine
\end{tabular}

Murugan et al. [5]

TPO and diesel

Murugan et al. [6]

DTPO (distilled tire pyrolysis oil) TPO and diesel

Murugan et al. [7]

Diesel and DTPO

Martínez et al. [8]

Diesel and TPO

Sharma and Murugan [9]

TPO and biodiesel (JME, Jatropha methyl ester)

Sharma and Murugan [10] TPO and biodiesel (JME)

Martínez et al. [11]

TPO and diesel

Koc and Abdullah [12]

TPO, biodiesel and diesel

Diesel, biodiesel and TPO
Diesel engine

Diesel engine

Diesel engine

Diesel engine

Description

It compared the emissions generated from the burning of TPO and diesel in a furnace, comparing the generated values in each one of them

It studied the performance, emissions and combustion characteristics of mixtures on volumetric basis with pure diesel mixed with DTPO at $80 \%$ and $90 \%$

It used a mixture of TPO/diesel in an internal combustion engine of a cylinder, with amounts of 10, 30 and $50 \%$ of TPO

Diesel engine

It compared the performance, emissions and combustion characteristics of mixtures using DTPO/diesel and TPO/diesel. The mixtures were $30 \%$ DTPO and $70 \%$ diesel and 30\% TPO and $70 \%$ Diesel

Three experimental tests were performed using pure diesel and mixtures of $80 \%$ DTPO with $20 \%$ diesel and 90\% DTPO with 10\% diesel, both mixtures in volumetric basis. Performance, emissions and combustion in a singlecylinder engine were compared by comparing performance with DTPO blends and diesel operation

The properties of the TPO volumetric mixtures with diesel were determined. Density, viscosity, lubricity, smoke point, water content, cold filter plugging point, oxidation stability and both higher and lower heating values were determined

JME, TPO and TPO at low percentages (10-50\% at regular intervals of $10 \%$ on a volume basis) were blended with JME at 90-50\%, respectively, in a diesel engine with a developing power of $4.4 \mathrm{~kW}$ at $1500 \mathrm{rpm}$

Diesel engine

The effects of fuel injection pressure on the performance and exhaust emission characteristics of a single-cylinder, constant speed and direct injection diesel engine have been investigated and compared with diesel. The engine fueled with JME-TPO blend (JME $80 \%+$ TPO $20 \%$ on a volume basis) was run at five different fuel injection pressures (200, 210, 220, 230, 240 and 250 bar)

TPO was mixed in an amount of $5 \%$ by volume with $95 \%$ diesel and then tested on a four-cylinder engine. The operating characteristics of the engine were obtained: engine performance, combustion process, gaseous emissions and smoke opacity, particulate matter and particle size distributions

Diesel engine

$10 \%$ of TPO, $10 \%$ of biodiesel and $80 \%$ of diesel were mixed to be used in a four-cylinder diesel engine

Diesel engine It was used in a four-cylinder engine with pure diesel (neat diesel), biodiesel, 50\% diesel blend with $50 \%$ biodiesel, commercial diesel and a blend of $95 \%$ commercial diesel with $5 \%$ TPO (volumetric base) 
Table 1 (continued)

\begin{tabular}{|c|c|c|c|}
\hline Authors (year) & Liquid & Device & Description \\
\hline García-Contreras et al. [14] & TPO and diesel & Residential boiler & $\begin{array}{l}\text { A } 50 \% \text { TPO blend with } 50 \% \text { diesel was used in } \\
\text { a residential boiler with a nominal power of } \\
29.1 \mathrm{~kW}\end{array}$ \\
\hline Sharma and Murugan [15] & TPO and biodiesel (JME) & Diesel engine & $\begin{array}{l}\text { A mixture of } 20 \% \text { TPO with } 80 \% \text { JME was } \\
\text { used in a } 4.4-\mathrm{kW} \text { one-cylinder engine, and } \\
\text { the study was performed on the combustion, } \\
\text { engine performance and emissions generated }\end{array}$ \\
\hline Sharma and Murugan [16] & TPO and biodiesel (JME) & Diesel engine & $\begin{array}{l}\text { Experiments were conducted with blends of } \\
\text { JME-TPO, in a single-cylinder diesel engine } \\
\text { at the advanced }\left(24.5^{\circ} \mathrm{CA} \text { bTDC), standard }\right. \\
\left(23^{\circ} \mathrm{CA} \text { bTDC), and retarded IT }\left(21.5^{\circ} \mathrm{CA}\right.\right. \\
\text { bTDC) and were compared with diesel fuel } \\
\text { and also with JME operation }\end{array}$ \\
\hline Wang et al. [17] & ТPO & Diesel engine & $\begin{array}{l}\text { TPO produced at temperatures of } 350,400 \text { and } \\
450{ }^{\circ} \mathrm{C} \text { was used in a diesel engine, for which } \\
\text { they were mixed with diesel, obtaining the } \\
\text { following mixtures: } 10 \% \text { TPO with } 90 \% \text { die- } \\
\text { sel and } 20 \% \text { TPO with } 80 \% \text { diesel, and lastly, } \\
\text { it was compared with standard diesel }\end{array}$ \\
\hline Pilusa [18] & ТPO & Diesel engine & $\begin{array}{l}\text { The behavior of TPO previously modified by } \\
\text { fractional distillation, which includes desul- } \\
\text { furization, adsorption, filtration and chemical } \\
\text { modification. This fuel was used and tested } \\
\text { on a six-cylinder truck engine }\end{array}$ \\
\hline Hürdoğan et al. [19] & TPO and diesel & Diesel engine & $\begin{array}{l}\text { TPO was mixed with diesel adding } 10,20 \text { and } \\
50 \% \text { TPO to then analyze the performance } \\
\text { and emissions generated in an internal com- } \\
\text { bustion engine }\end{array}$ \\
\hline Vihar et al. [20] & ТPO & Diesel engine & $\begin{array}{l}\text { In a four-cylinder engine, the use of TPO was } \\
\text { tested for different rates of exhaust gas recir- } \\
\text { culation and different injection parameters in } \\
\text { order to evaluate its impact on the combus- } \\
\text { tion process and the formation of emissions }\end{array}$ \\
\hline Sharma and Murugan [21] & TPO and biodiesel (JME) & Diesel engine & $\begin{array}{l}20 \%, 40 \%, 60 \% \text { by volume of TPO were mixed } \\
\text { with JME (biodiesel) to test the antioxidant } \\
\text { effects on biodiesel and to evaluate its effects } \\
\text { on engine performance }\end{array}$ \\
\hline
\end{tabular}

\section{Used tire pyrolysis}

\subsection{Tire manufacturing process}

Tire manufacturing involves, among other materials, layers of rubber, textile ropes, steel strips and additives to improve their performance according to their intended use.

According to the IRSG (International Rubber Study Group), worldwide tire production was $15,947.00$ million tons in 2016, which represents a $3 \%$ increase over the previous year (Fig. 1) [2, 23].

There are many ways to dispose of tires in the world, including recovery in civil works in the form of blocks or as additives, recovery of raw materials, retreading, etc. An important tire recovery option is as a source of energy in co-incineration with other wastes that use about 0.1 million tons of tires per year in cement factories [24].
In 2015 and 2016, Brazil industries had a turnover of 71.9 and 70.7 million tires, respectively, according to ANIP (National Association of Tire Industry), thus revealing a fall in continuous production since 2013, as shown in Fig. 2 [25].

The amount of sulfur found in tires is between 0.5 and $2.0 \mathrm{wt} \%$, i.e., less than or equal to most quantities in coal and petroleum coke in general, while that observed in TPO is between 1.0 and $1.4 \mathrm{wt} \%$ which make a necessary posttreatment to avoid the formation of SOx [26, 27]. The same occurs with hydrocarbons that constitute tire rubber, which are no more complex or difficult to be destroyed than those present in coal $[24,28,29]$.

\subsection{Used tire disposal}

In order to solve the waste disposal problem, there are several mechanisms to assist governments in ensuring a correct 
Fig. 1 Amount of tires manufactured worldwide in 2016 in tons $(\times 10000)[2]$
Fig. 2 Tire sales volume in millions (by ANIP) [25]

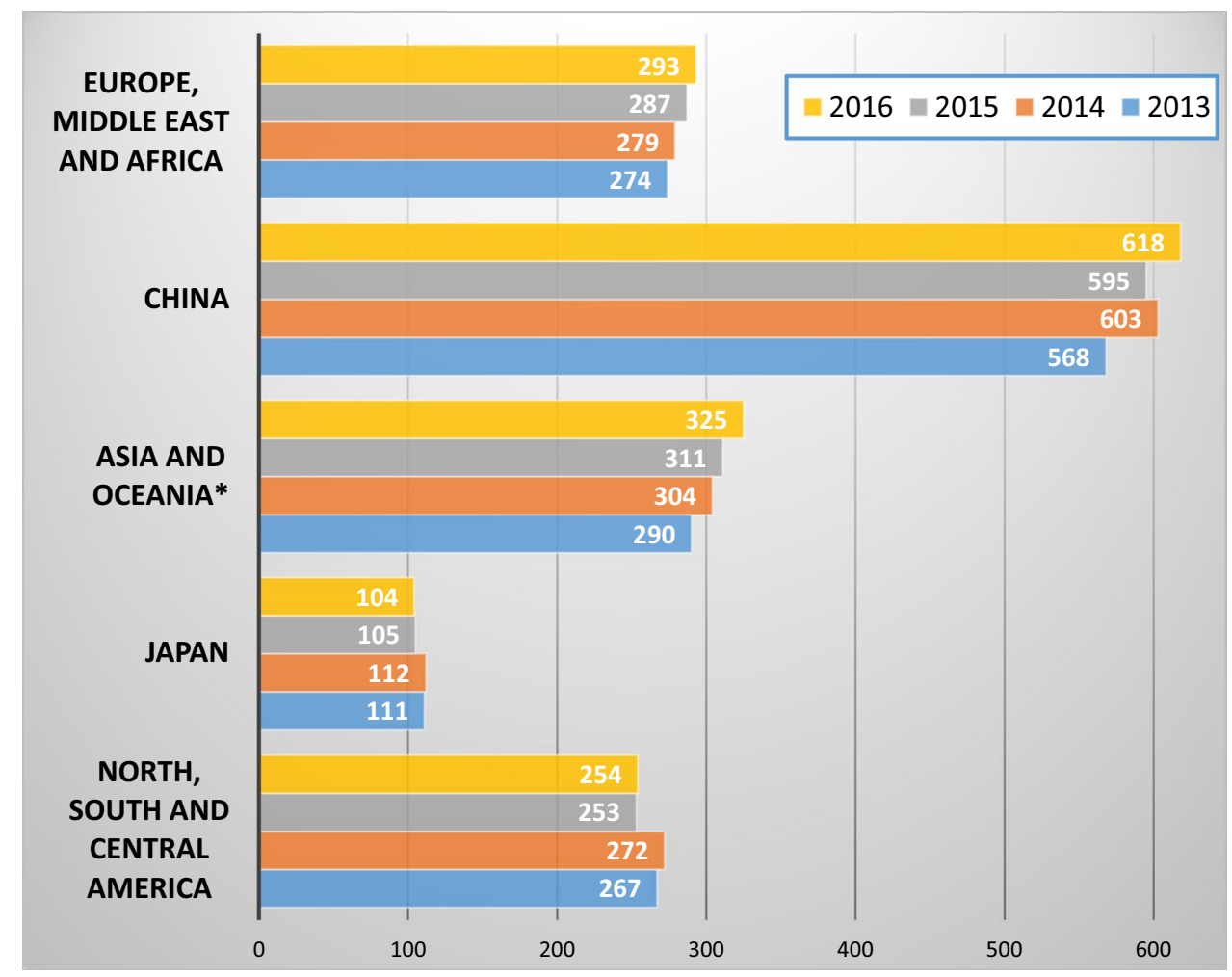

* Excluding China and Japan

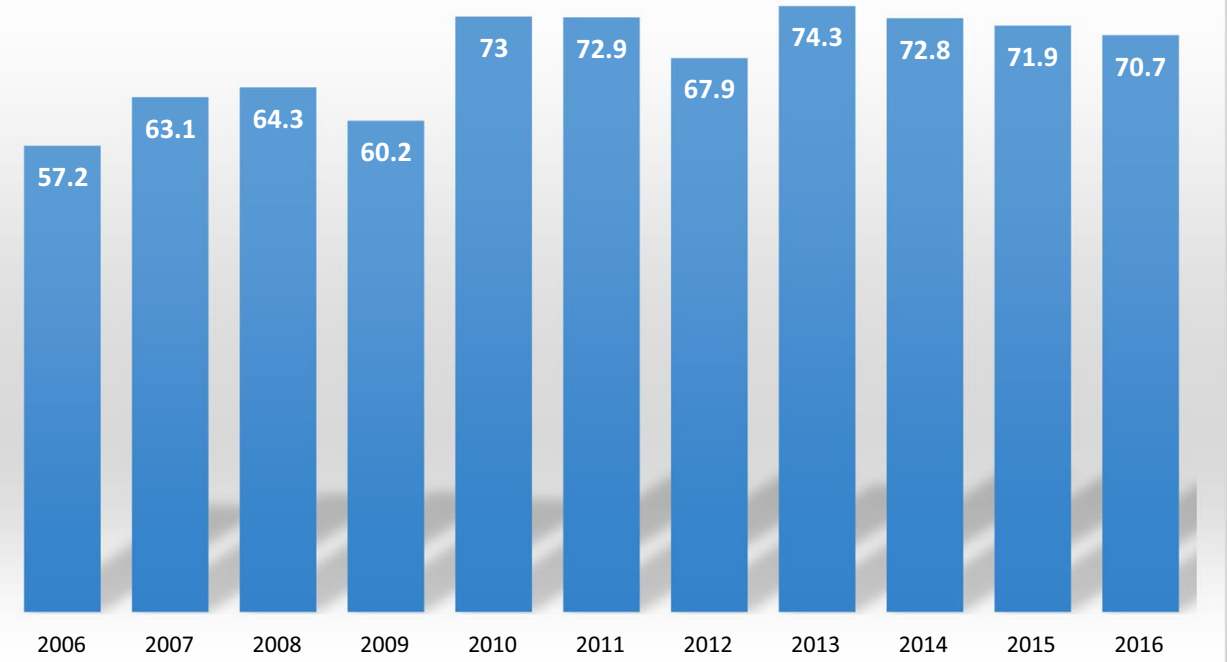

disposal, one which is the extended producer responsibility in which manufacturers are responsible for a correct disposal of waste generated at the end of their product use, which has been used in the case of Brazil for some time.

Within the European Union (EU) legislation, some waste treatment targets have been found. Among them, according to the Landfill Directive (1991/31/EC), the amount of waste tires in these landfills would be $0 \%$ in 2006 [30]. For such a purpose, tire manufacturing companies have progressively implemented these targets in the EU member states in order to achieve them together.

In Brazil, Resolution No. 416 from September 30, 2009, established by the National Environment Council (CONAMA) regulates used tire disposal, which states that 
manufacturing companies or importers should be accountable for a proper disposal of every new tire for sale in the aftermarket.

Furthermore, manufacturers and importers of new tires are expected to implement at least one area for collecting used tires in municipalities with over a hundred thousand inhabitants.

In addition, when a used tire is replaced by a new or refurbished one, tire retailers are obliged to temporarily receive and store the used tires delivered by consumers. RECICLANIP, an entity created by tire manufacturers which is exclusively aimed at collecting and disposing of tires in Brazil, is responsible for the areas of tire collection, in accordance with the management model of European companies to collect and dispose of waste tires, such as Alipur in France, SIGNUS in Spain and Valorpneu in Portugal, which bear the costs of used tire collection and disposal [31].

\subsection{Energy alternatives for waste tire use}

Environmentally friendly disposal technologies that are used by companies in Brazil are:

a) Co-processing Use of waste tires in clinker kilns as a partial substitute for fuels and as a source of metallic elements. In Brazil, co-processing is used in duly licensed plants according to environmental agencies.

b) Lamination Manufacturing process of rubber goods.

c) Granulation Industrial manufacturing process of rubber ground, in different granulometries, with steel separation and use for later reutilization in other industries.

d) Shale industrialization Industrial stage of co-processing used tires together with bituminous shale as a partial fuel replacement. This process is carried out at an operations unit located in São Mateus do Sul, which belongs to
Petrobras, with installed capacity of 5880.00 tons/day. In this process, liquid fractions are obtained through a pyrolysis process, which are then converted into commercial fuels and fertilizers [32].

e) Pyrolysis Thermal decomposition process of rubber carried out in the absence of oxygen or under conditions where oxygen concentration is low enough so as not to generate combustion, oils, gas and carbon black (char) [33].

\subsection{TPO characterization}

The main advantage of pyrolysis is that it is able to treat wastes that are difficult to be recycled and then make them reusable by breaking them down into lighter elements. This treatment is used to convert residues into fuels with higher heating value, chemicals, monomers and other valuable materials that can be used for other purposes [34].

It is known that discarded tires have high volatile content, a higher ash content and higher heating value than those of coal and traditional biomass, thus being ideal for pyrolysis, combustion and gasification $[35,36]$.

As it can be seen in Table 2, TPO has a similar heating value to that of fossil fuels, as kerosene, diesel and light fuel oil; thereby, its use in internal combustion engines and gas turbines is rather interesting [17, 34, 37].

Furthermore, Table 2 shows high sulfur content in TPO composition if compared to other fuels. The presence of sulfur leads to the generation of pollutants containing sulfur oxides.

The physicochemical composition of the liquid fuel resulting from pyrolysis, as shown in Table 3, presents several values depending on a few factors, such as tire and pyrolysis process type, reaction time and reaction temperature.
Table 2 Physical-chemical properties of OPPU if compared to traditional fuels

\begin{tabular}{|c|c|c|c|c|c|}
\hline Property & TPO [24] & Kerosene [38] & Gas oil [38] & $\begin{array}{l}\text { Light fuel } \\
\text { oil [38] }\end{array}$ & Diesel [20] \\
\hline Flash point $\left({ }^{\circ} \mathrm{C}\right)$ & 20 & 40 & 75 & 79 & $50.0^{\mathrm{a}}$ \\
\hline Carbon residue (\%) & 2.2 & - & $<0.35$ & - & - \\
\hline Density $\left(\mathrm{kg} \mathrm{l}^{-1}\right)$ & 0.91 & 0.84 & 0.78 & 0.89 & 0.83 \\
\hline Viscosity (cSt) a $40^{\circ} \mathrm{C}$ & 6.3 & 1.2 & 3.3 & 21 & 2.54 \\
\hline Carbon (wt\%) & 88 & - & 87.1 & 85.5 & 87.0 \\
\hline Hydrogen (wt\%) & 9.4 & 13.6 & 12.8 & 12.4 & 13.0 \\
\hline Nitrogen (wt \%) & 0.45 & - & 0.05 & 0.15 & - \\
\hline Sulfur (wt\%) & 1.5 & 0.1 & 0.9 & 1.4 & $<0.001$ \\
\hline Oxygen (wt\%) & 0.5 & - & - & - & - \\
\hline Calorific value $\left(\mathrm{MJ} \mathrm{kg}^{-1}\right)$ & 42 & 46.6 & 46 & 44.8 & 42.95 \\
\hline Ash (wt\%) & 0.002 & - & 0.01 & 0.02 & $<0.01$ \\
\hline Moisture (vol \%) & 4.6 & - & 0.05 & 0.1 & $0.00^{\mathrm{a}}$ \\
\hline
\end{tabular}

${ }^{\mathrm{a}} \mathrm{Koc}$ and Abdullah [12] 
Table 3 Element composition properties of OPPU according to several authors

\begin{tabular}{|c|c|c|c|c|c|c|c|c|c|c|c|c|c|}
\hline Characteristics & {$[3]$} & [41] & [42] & [43] & [44] & [13] & [45] & [46] & [47] & [17] & [39] & [40] & TPO \\
\hline C & 88 & 86.5 & 87.82 & 84.26 & 85.86 & 83.48 & 81.18 & 86.87 & 68.91 & 86.19 & 81.04 & 87.72 & 87.1 \\
\hline $\mathrm{H}$ & 9.4 & 10.8 & 9.42 & 10.39 & 9.15 & 13.12 & 10.92 & 10.07 & 9.6 & 10.33 & 11.11 & 11.31 & 9.65 \\
\hline $\mathrm{N}$ & 0.45 & 0.5 & 0.55 & 0.42 & 0.65 & 0.22 & 1.85 & 1.184 & 2.05 & 0.79 & 0.5 & 0.23 & 0.6 \\
\hline $\mathrm{O}$ & 0.5 & 2.2 & 0 & 3.39 & 2.87 & 2.46 & 4.62 & 1.169 & 18.37 & 0 & 6.76 & - & 1.76 \\
\hline$S$ & 1.45 & - & 2.21 & 1.54 & 1.25 & 0.72 & 0.031 & 0.906 & 1.07 & 0.83 & 0.59 & 0.7 & 0.89 \\
\hline Ash & 0.002 & - & - & - & 0.22 & 4.81 & 0.31 & - & - & - & - & - & $<0.01$ \\
\hline Heating value (MJ/kg) & 42 & - & - & - & - & - & 38 & 43.34 & - & - & - & - & - \\
\hline Higher heating value $(\mathrm{MJ} / \mathrm{kg})$ & - & 43.7 & 42.49 & - & 42 & - & - & - & 42.61 & 42.7 & 43.8 & $47 \pm 5$ & 42,015 \\
\hline Lower heating value $(\mathrm{MJ} / \mathrm{kg})$ & - & - & - & 41.7 & - & 38 & - & - & - & 40.49 & - & $45 \pm 0.4$ & $39.891^{\mathrm{a}}$ \\
\hline Density $\left(\mathrm{kg} / \mathrm{m}^{3}\right)$ & 910 & $950^{\mathrm{b}}$ & - & 941 & 957 & $923.9^{c}$ & $935^{\mathrm{c}}$ & $945^{\mathrm{b}}$ & 820 & $917^{\mathrm{c}}$ & 875 & 900 & $920.7^{\mathrm{b}}$ \\
\hline Viscosity (cSt) & $6.3^{\mathrm{d}}$ & $9.7^{\mathrm{e}}$ & - & $2.44^{\mathrm{e}}$ & $4.75^{\mathrm{f}}$ & $3.77^{\mathrm{d}}$ & $3.2^{\mathrm{d}}$ & $3.8^{\mathrm{d}}$ & $0.95^{\mathrm{e}}$ & $2.39^{\mathrm{d}}$ & $1.7^{\mathrm{d}}$ & 2.867 & 5.153 \\
\hline
\end{tabular}

TPO TPO-UNIFEI

${ }^{\mathrm{a} C}$ Calculated from elemental composition

${ }^{\mathrm{b}} 20{ }^{\circ} \mathrm{C}$

${ }^{\mathrm{c}} 15^{\circ} \mathrm{C}$

${ }^{\mathrm{d}} 40{ }^{\circ} \mathrm{C}$

${ }^{\mathrm{e}} 50{ }^{\circ} \mathrm{C}$

${ }^{\mathrm{f}} 30^{\circ} \mathrm{C}$

The following TPO properties were experimentally determined:

Determination of carbon, hydrogen and nitrogen content by using a gas analyzer and an analytical balance according to ASTM D5291-10 (15); determination of total ash content by using a muffle, an analytical balance and a thermometer according to ASTM D482-13; determination of total sulfur content by means of a sulfur analyzer and an analytical balance according to ASTM D1552-15; determination of density by using a digital density meter at $20{ }^{\circ} \mathrm{C}$ according to ASTM D4052-11; viscosity determination by using two pieces of equipment: an Ostwald viscometer and a QUIMIS rotary viscometer, thus obtaining the mean value of the two measurements. Finally, the determination of surface tension was also obtained through two items of equipment: a Du Nouy tension meter and a LAUDA TD 3 tension meter. The results of these measurements are presented in Tables 3, 4 $[3,4,8,39-47]$.

\subsection{Atomization}

In combustion processes, the liquid fuel must be disintegrated into small droplets so as to ensure a rapid vaporization and heat transfer. The fundamental principle of disintegration of a liquid consists in increasing fluid surface area until it becomes unstable and disintegrates, by three mechanisms: turbulent, aerodynamic and microexplosive. This process in which the liquid becomes droplets depends on the type of flow, atomizer geometry, temperature and ambient pressure. The basic mechanism consists essentially in breaking up the unstable bulk liquid into droplets, which depends on its length and circumference [48-51].

A fuel atomization prior to its injection into the combustion chamber is fundamental to achieve efficient combustion and performance of an industrial furnace for instance, as it generates a high surface-area-to-volume ratio in the liquid phase, thus promoting fuel evaporation and combustion [48].

To characterize the atomizer droplet size, representative measures of droplet size at its nozzle were used [52, 53], which are:

Mass median diameter (MMD), i.e., representative diameter so that $50 \%$ of the atomized liquid total mass consists of droplets with diameters greater than the indicated value, while $50 \%$ is composed of droplets with diameters that are smaller than the indicated value, whose value is the same as the volume median diameter (VMD). [54]
Table 4 Properties of liquids used in injectors

\begin{tabular}{llllll}
\hline Liquid & TPO & Diesel & TPO 2\% & TPO 5\% & TPO 10\% \\
\hline Density $\left(\mathrm{kg} / \mathrm{m}^{3}\right)$ & 920.7 & 830.19 & 813.59 & 810.07 & 809.05 \\
Viscosity $(\mathrm{Pa} \mathrm{s})$ & $47 \times 10^{-5}$ & $3.1 \times 10^{-3}$ & $3 \times 10^{-4}$ & $33 \times 10^{-4}$ & $32 \times 10^{-4}$ \\
Surface tension $(\mathrm{N} / \mathrm{m})$ & 0.028 & 0.026 & 0.013 & 0.012 & 0.012 \\
\hline
\end{tabular}


Sauter mean diameter (SMD), i.e., the diameter of a droplet whose surface-to-volume ratio is the same as that of all sprayings [55].

The SMD is often used in the literature to characterize the droplet size generated by the spray, but the Wigg equation determines the MMD; for this reason both parameters were determined experimentally using the SMD to characterize the spray and the MMD for comparison with the theoretical results $[56,57]$.

\subsection{Y-Jet atomizer}

An air-assisted atomizer due to having an auxiliary fluid (air or steam) at high speed on a liquid fuel is used, which is the reason why atomization is influenced by the atomizer pressure and geometric configuration, and properties of the fluids being used [55, 58-62]. Atomization, which is fundamental to fuel combustion quality, also influences the generation of pollutants, i.e., a major issue in current efforts to combat environmental contamination [63, 64].

The atomizing mechanism starts in the mixing chamber with the liquid jet which is atomized by the high pressure gas, thus causing liquid disintegration and a film formation with an annular undulating surface on the walls of the chamber. Due to the undulating perturbations generated inside the mixing chamber, the liquid film upon the injector outlet disintegrates into small droplets which, in the case of fuels, can be burned inside a combustion chamber [48], whose liquid disintegration process is shown in Fig. 3.

The main internal dimensions of a Y-Jet atomizer are shown in Fig. 4, which presents two fluid supply ducts (fuel and air), where the liquid is supplied through the inclined duct, and the gas is supplied through the horizontal duct, and then, both are blended in the mixing chamber which has a larger diameter.

Some methodologies have been proposed and studied for designing this atomizer, being the methodology presented by Mullinger and Chigier [65], which was later used by Lacava et al. [67], Lacava et al. [59] and Quispe [66]. This methodology contains the recommended design parameters, shown in Table 5 [59, 65-67].

\section{Methodology}

Along this work development, the following phases were carried out: Firstly, the Y-Jet atomizer was designed by following the recommendations given in the specialized literature (see previous section); afterward, a liquid atomization test bench was built in order to analyze different types of atomizers, fossil fuels and biofuels. Next, the Y-Jet atomizer was built and tested in polymethyl methacrylate, PMMA and then in stainless steel for pure TPO and in blends with diesel ( $2 \%$ and $10 \%$ in mass) on the test bench.

The final phase consisted in determining droplet size by using the Malvern Spraytec 2007 laser diffraction system, model STP5936. Once this parameter was determined, the values were compared with those calculated according to Wigg's equation (Eq. 5). The latter equation allows a theoretical calculation of mean droplet diameter. In addition, atomization cone angle measurements were taken for all mixtures.

The TPO was supplied by a company in the concreting service business in Brazil (Polimix, SA), and the S-10 diesel was used which regulates the amount of sulfur contained in it, being less than $10 \mathrm{ppm}$ in weight. As regards the diesel used in the blends, the Shell Evolux Diesel S-10 fuel was used, which is composed of $93 \%$ S-10 diesel oil in volume, $7 \%$ biodiesel in volume, besides an property-improving additive containing a typical lower heating value of $10,250 \mathrm{kcal} /$ $\mathrm{kg}(42,914.7 \mathrm{~kJ} / \mathrm{kg})$.

\subsection{Y-Jet atomizer dimensioning}

In the calculation of geometric parameters of the atomizer, flow is represented by a single-phase air flow, according to Eqs. (1-4) for compressible flow:

$T^{*}=T_{0}\left(\frac{2}{k+1}\right)$

$p^{*}=p_{0}\left(\frac{2}{k+1}\right)^{\frac{k}{k-1}}$

$\rho^{*}=\frac{p^{*}}{R T^{*}}$

$A_{g}^{*}=m^{*} \frac{\sqrt{R T_{0}}}{p_{0} \sqrt{k}}\left(\frac{2}{k+1}\right)^{-\frac{k+1}{2(k-1)}}$

Droplet size is theoretically calculated according to Wigg's equation:

$D_{\mathrm{MMD}}=\frac{200 v_{L}^{0.5} \dot{m}_{L}^{0.1}\left(1+\dot{m}_{L} / \dot{m}_{A}\right)^{0.5} h^{0.1} \sigma^{0.2}}{\rho_{A}^{0.3} U_{A}}$

As an example, an atomizer operating with $35 \mathrm{~kW}$ of thermal power by taking into account its use in small combustion chambers, whose parameters and dimensions are shown in Tables 5 and 6, was calculated. The adopted dimensions were based on machining and construction constraints, being the final configuration composed of two parts, as shown in Fig. 5. For further details, see the illustrative calculation 
Fig. 3 Liquid atomization in a Y-Jet atomizer [49]

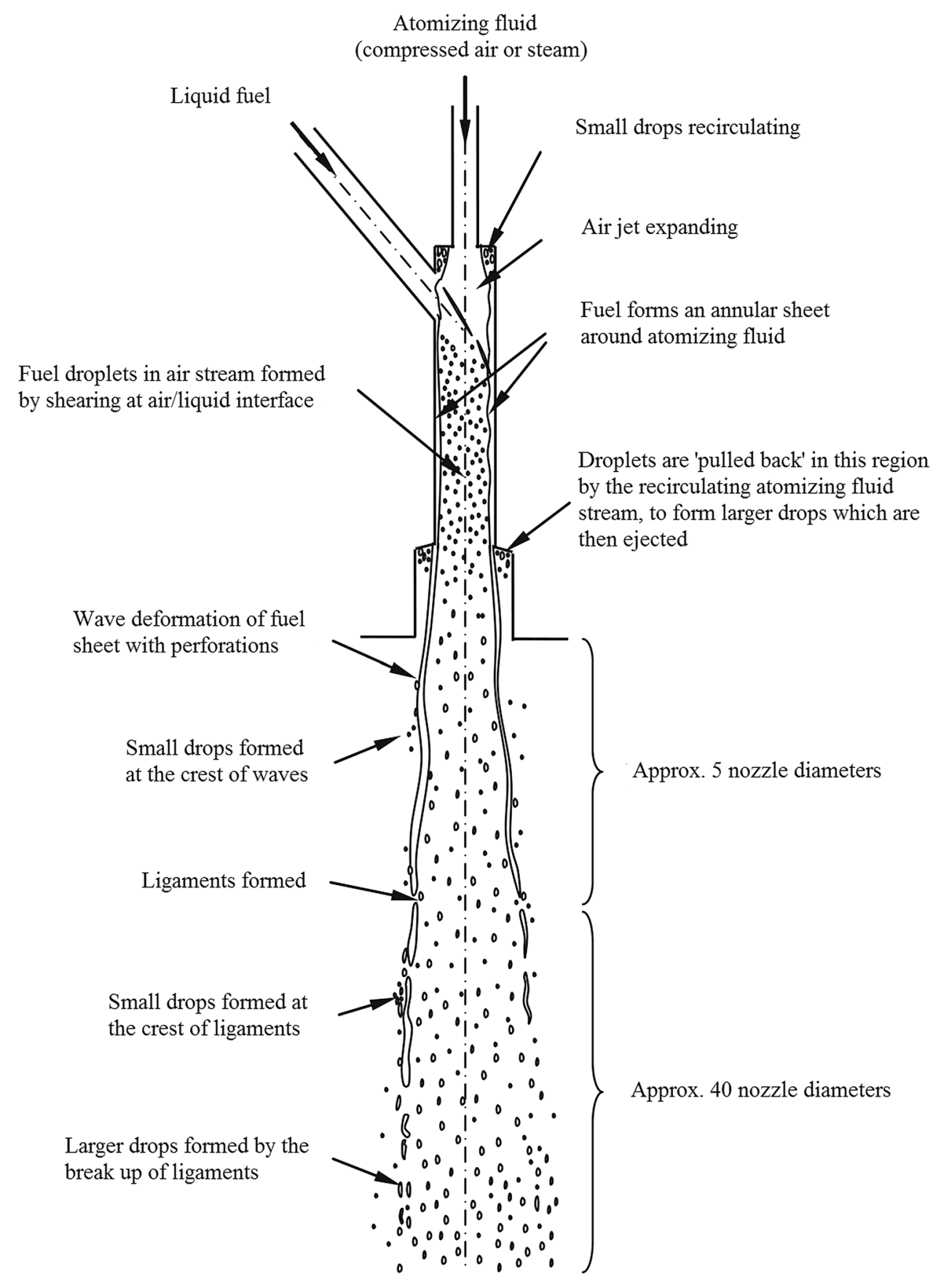

Atomizing fluid

compressed air or steam)

with sight gauge, five open/close valves for each fuel cylinder, one centrifugal compressor, two flow-regulating needle valves, a $200-\mathrm{ml} / \mathrm{min}$ needle valve rotameter, one GFM AALBORG air flow meter, four N1540 universal indicators, two Huba Control 520 relative pressure transmitters, one thermocouple type K, one inverter, CFW08 $220 \mathrm{~V}$ 0026S2024PSZ 0,5 CV STD, 1/8" stainless steel pipes, connections, curves and T-shaped stainless steel and one open-close valve (for atomizing air regulation).

Its operation is summarized by the scheme shown in Fig. 8. There are two tanks containing synthetic air and rack Hi top 19 " $-44 \mathrm{U}-600 \mathrm{~mm}$, two cylindrical fuel tanks 
Fig. 4 Schematic of a Y-Jet atomizer and its main dimensions [65]

Table 5 Recommendations for designing the dimensions of a Y-Jet atomizer and values adopted for Y-Jet atomizer sizing [66]

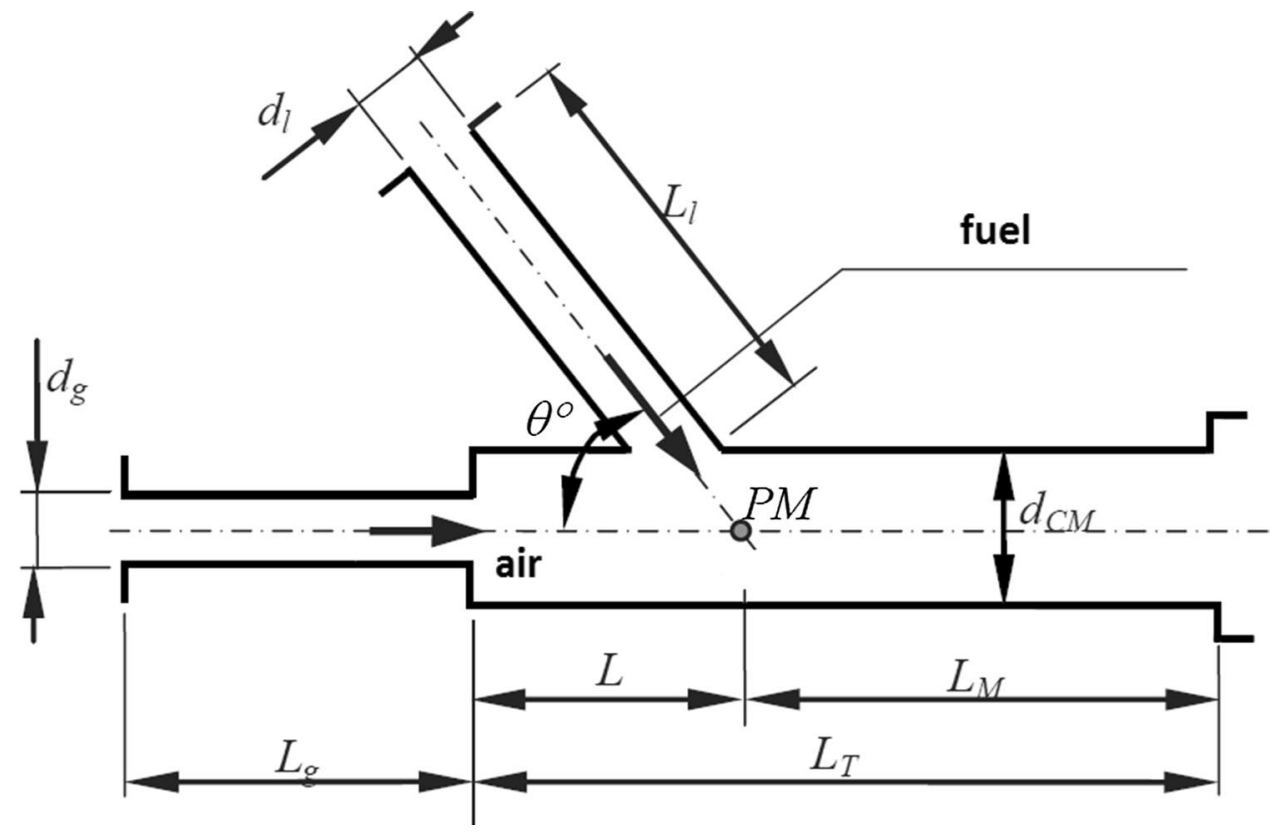

\begin{tabular}{llll}
\hline Parameter & Recommended & Adopted & $35 \mathrm{~kW}$ \\
\hline 1. Atomizing gas duct diameter, $d_{\mathrm{g}}(\mathrm{mm})$ & $d_{\mathrm{g}}$ (calculated) & $d_{\mathrm{g}}$ & 0.5 \\
2. Diameter of the fuel supply duct, $d_{\mathrm{l}}(\mathrm{mm})$ & $d_{\mathrm{l}}=d_{\mathrm{g}}$ & $d_{\mathrm{g}}=d_{\mathrm{l}}$ & 0.5 \\
3. Diameter of the mixing chamber, $d_{\mathrm{M}}(\mathrm{mm})$ & $(1.4-1.8) d_{\mathrm{g}}$ & $d_{\mathrm{M}}=(1.8) d_{\mathrm{g}}$ & 0.9 \\
4. Premix length, $L(\mathrm{~mm})$ & $(1-2) d_{\mathrm{g}}$ & $L=(1.63) d_{\mathrm{g}}$ & 0.8 \\
5. Mixing length, $L_{\mathrm{M}}(\mathrm{mm})$ & $(4-5) d_{\mathrm{g}}$ & $L_{\mathrm{M}}=(4.5) d_{\mathrm{g}}$ & 2.2 \\
6. Mixing chamber total length, $L_{\mathrm{T}}(\mathrm{mm})$ & $L+L_{\mathrm{M}}$ & $L_{\mathrm{T}}=L+L_{\mathrm{M}}$ & 3.0 \\
7. Length of the atomizing gas-feeding duct, $L_{\mathrm{g}}(\mathrm{mm})$ & $>2 d_{\mathrm{g}}$ & $L_{\mathrm{g}}=2.55 d_{\mathrm{g}}$ & 2.5 \\
8. Length of fuel supply duct, $L_{\mathrm{l}}(\mathrm{mm})$ & $>2 d_{\mathrm{g}}$ & $L_{\mathrm{g}}=2.55 d_{\mathrm{g}}$ & 2.5 \\
9. Fuel rod feeding hole angle, $\theta\left(^{\circ}\right)$ & $=52^{\circ}$ & $\vartheta$ & 52 \\
\hline
\end{tabular}

nitrogen (A and $B$ ), nitrogen supplies the pressure to fuel cylinders $(C$ and $D)$ and the line parameters are measured (pressure, temperature and volumetric flow rate with sensors G, H, I, K and L). The two lines supply the atomizer with gas and fuel $(\mathrm{M})$ at desired pressure and flow rate by using the valves (E, F and $\mathrm{J}$ ). A data acquisition and storage system was developed based on the Arduino platform by using LabVIEW ${ }^{\circledR}$ for visualizing and storing the results on a computer. The laser diffraction system to determine droplet size has its own data acquisition and post-processing software (Spraytec 3.20 Malvern).

The laser meter uses light diffraction or scattering of its beam as it passes through the spray. The diffraction is obtained by a Fourier lens which generates a distribution that is directed to a plate composed of photodiodes, which measures the scattering. The main function performed by Fourier lens is that any light scattered at the same angle by particles that are within the measuring zone is directed toward the same zone through the detection system. This is 


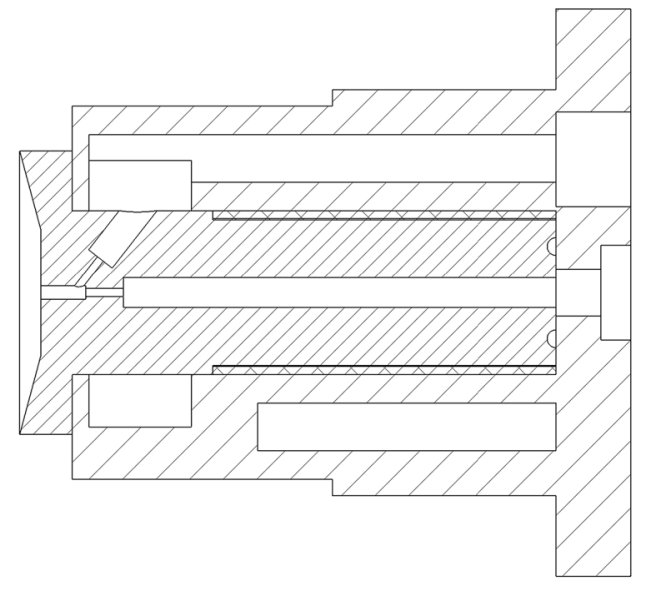

(a)

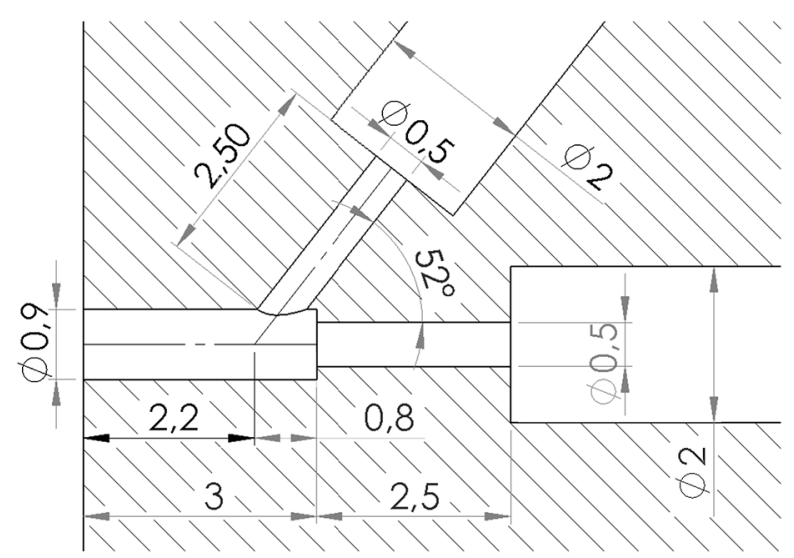

(b)

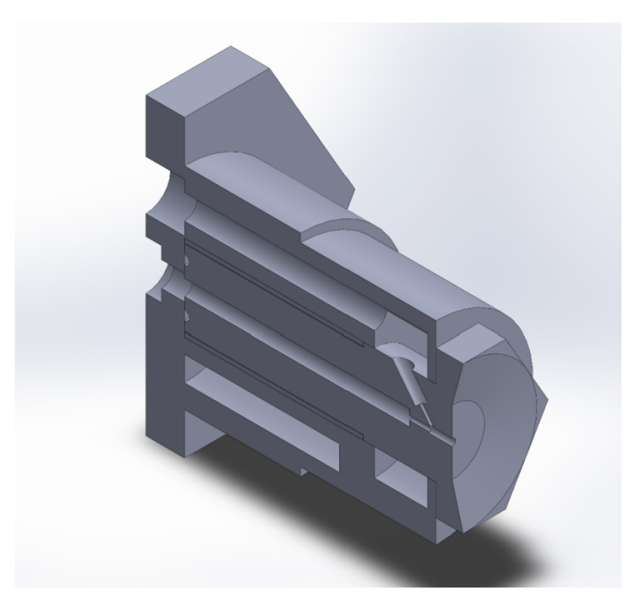

(c)

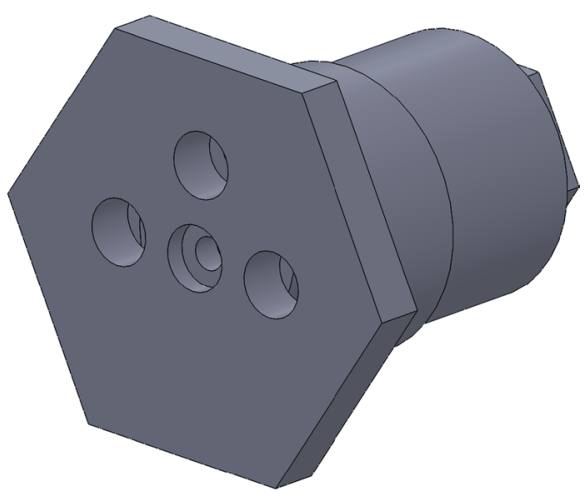

(d)

Fig. 5 Y-Jet atomizer dimensions: a assembly, $\mathbf{b}$ atomizer internal measurement details, $\mathbf{c}$ Y-Jet atomizer cross section, $\mathbf{d}$ atomizer rear detail

achieved regardless of speed or position of spray particles within the measuring zone, and in such a way that, at any time, the light scattering pattern measured by the detection system is an indicator of all particle size distributions present in the laser beam [68].

The Spraytec equipment operation fundamentals are as follows (Fig. 9):

a. Light from the laser (1) is dispersed by spray droplets (3).

b. The light is expanded by optical collimation (2) so as to provide a wide parallel light beam.

c. The scattered light is directed with focusing lens (4) in a Fourier arrangement and picked up by a set of detectors (5).

d. The undispersed light is directed through focusing lens (5) so that it passes through a hole in the middle of a set of detectors. This is measured by the beam power detector so as to provide light transmission.
The angle at which a particle diffracts light is inversely proportional to its size. The set of detectors is composed of about 30 individual detectors, each collecting light scattered over a particular range of angles [69].

\subsection{Experimental bench operation}

For the experimental bench operation, the amount of air to be used in the test $(4 \mathrm{~L} / \mathrm{min})$ is first regulated by the needle valve ( $\mathrm{J})$, and then, the fuel is supplied, which is measured at the lowest value that can be obtained by the rotameter which is used to calculate the highest GLR value. From this value, the fuel supply will decrease the GLR value until it reaches the highest value that can be measured by the rotameter, which is the highest GLR value. At the end of the tests, the liquid fuel must be evacuated from the lines due to its tendency of generating deposits, which could clog the line, which is the reason why the fuel line is purged with pure diesel until the whole line is immaculately clean. 


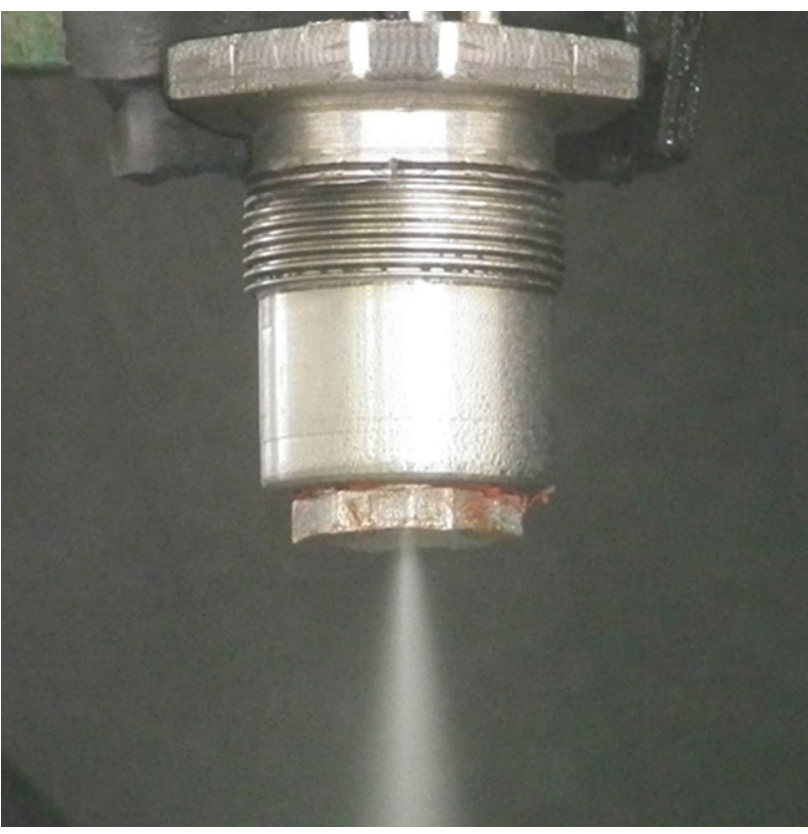

Fig. 6 Stainless-steel Y-jet atomizer

\section{Results and discussion}

Tire recycling is a problem due to its chemical composition, the amount of space it occupies, accidental burning, and could become mosquito breeding sites that transmit yellow fever, dengue, chikungunya, Zika, etc. The allowed processes for correct tire disposal in Brazil are co-processing, laminated granulation, shale industrialization and pyrolysis, being co-processing the process which has been most commonly used.

The Y-Jet atomizer built in this study has been tested with pure TPO and in blends with conventional S-10 diesel oil, whose properties are shown in Table 4. SMD was used to characterize droplet size; however, for comparing the droplet size with the results obtained theoretically by Eq. (5) (Wigg's equation), MMD was used.

Due to the test properties and characteristics, some safety precautions were taken into account: Firstly, the type of material for designing the atomizer was chosen by considering the TPO properties; on the other hand, due to the atomized liquid characteristics, a collection after it had been atomized is necessary in order to avoid the formation of fog inside the laboratory.

The Y-Jet atomizer has been tested with diesel and TPO mixtures, whose experimental results are shown in Figs. 10, 11 and 12. In Fig. 10a-c, droplet size behavior (SMD) is shown as regards pressures in fuel and air lines, and Fig. 11 shows droplet size variations (SMD) for diesel, diesel blended with $2 \%$ TPO and 10\% TPO. Finally, Fig. 12a-c shows the comparisons between experimental droplet size (MMD) and calculated droplet size (Wigg's Eq. 5).

In order to design the atomizers, it was necessary to characterize the fuel liquids that were tested in them; thus, each liquid used in the tests was measured as regards their main properties, such as chemical composition, heating value, density, viscosity and surface tension. The last three properties were the most important for the atomizers design and droplet size prediction.
Fig. 7 Experimental atomization test bench. a Rear view and b front view of the bench

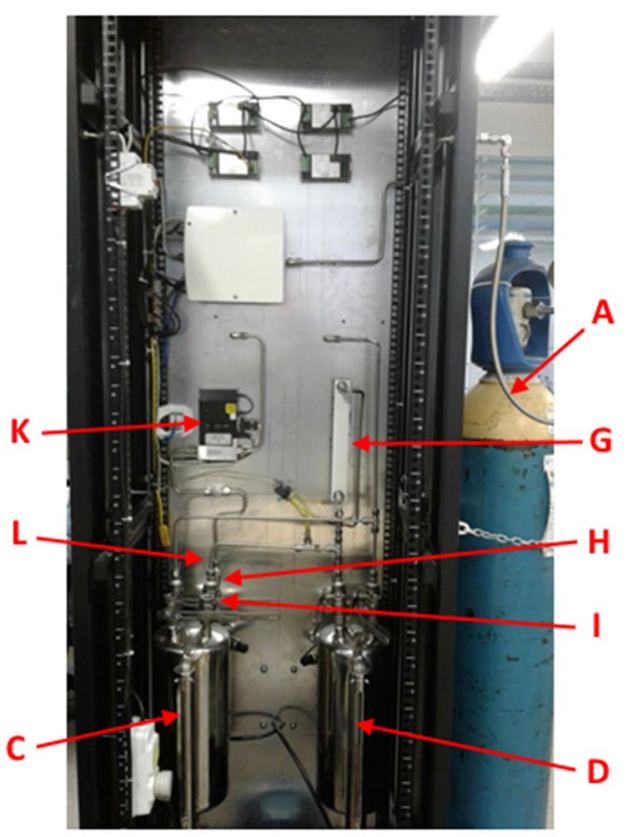

(a)

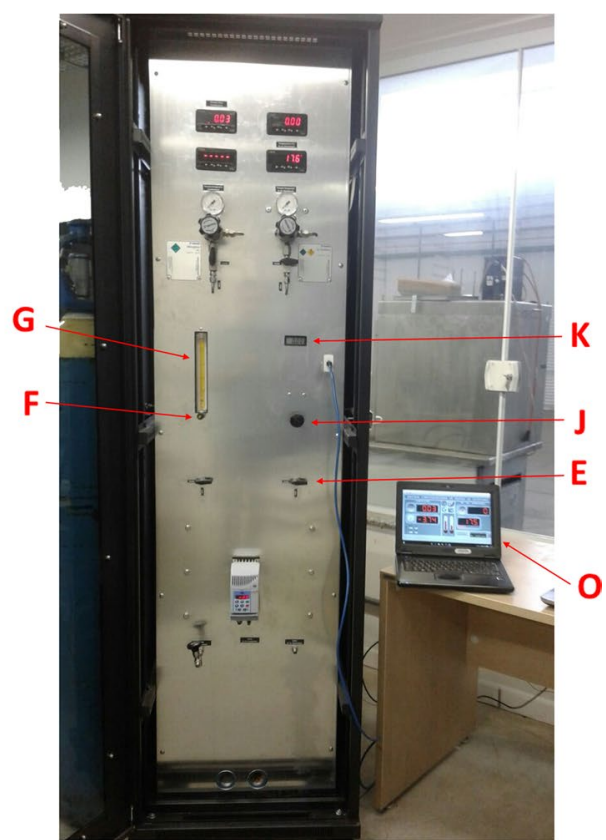

(b) 


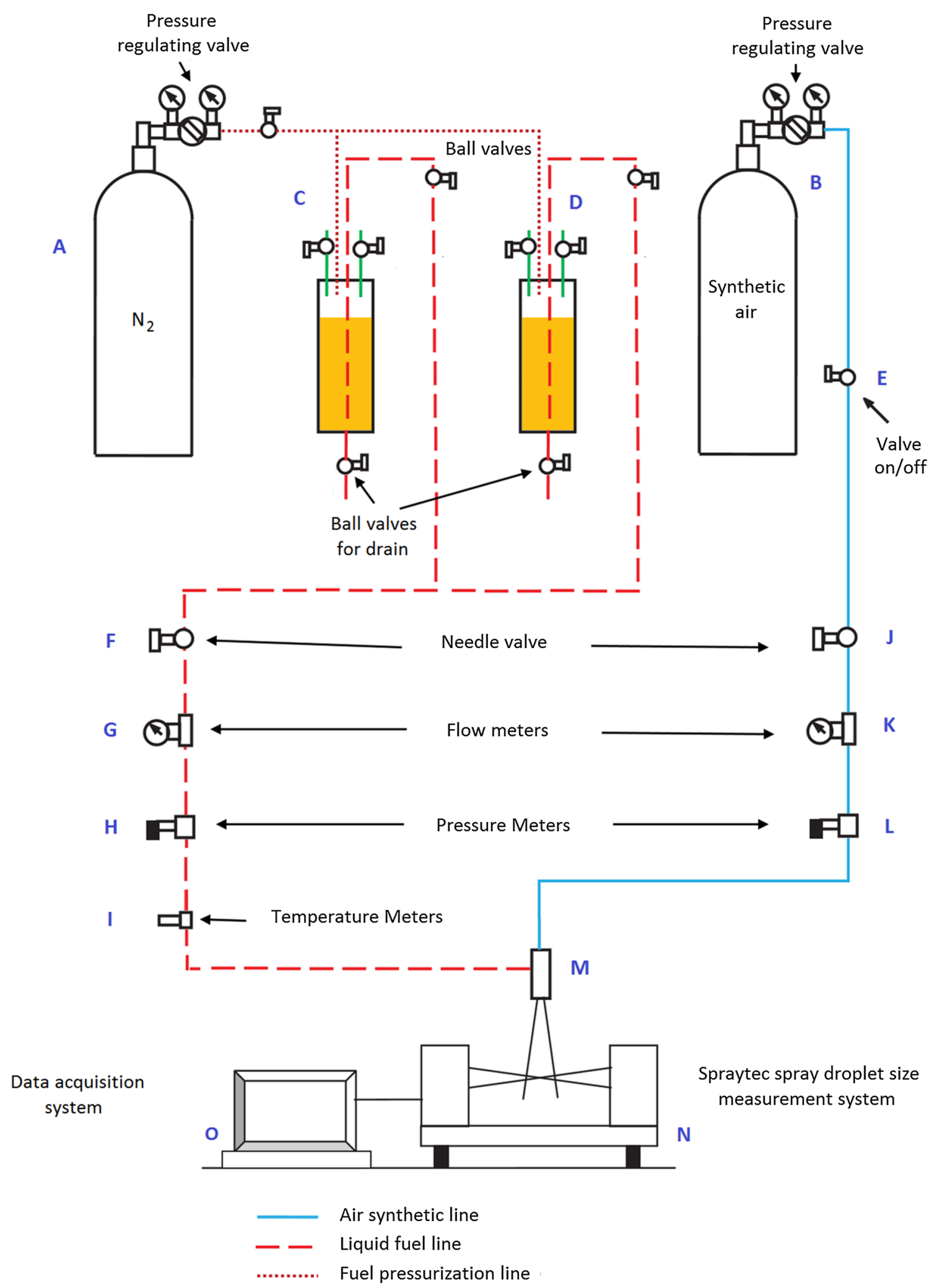

Fig. 8 Experimental bench layout for atomizer tests 
Fig. 9 Operation principle of the Spraytec system [69]

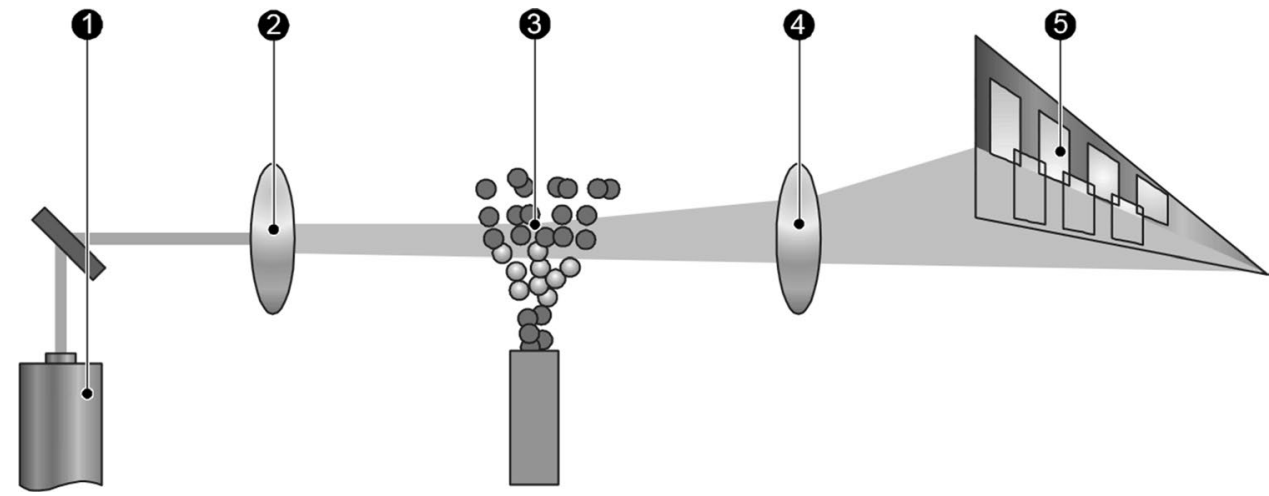

The experimental results show a sudden decrease in droplet size that occurs at the point where the liquid fuel pressure exceeds atomizing air pressure, which also presented a significant variation in droplet size for all tests.

The injector was designed according to the technical specifications found in the literature for single-phase flow under critical conditions. It was manufactured in two parts for greater ease of construction, maintenance, assembly and cleaning (Figure 5c, d).

The cone angle was measured experimentally for diesel with 2\% TPO (Fig. 13a, b), with 10\% TPO (Fig. 13c, d) and for pure diesel (Fig. 13e, f). The amount of TPO in the mixture does not greatly influence the spray angle, which ranges from 15 to 19 degrees, representing only a $4^{\circ}$ variation among all the fuels tested.

\section{Conclusion}

The automotive industry, in terms of tires, annually generates a large amount of waste that is difficult to be discarded, thus posing a problem that can be solved through the enforcement of environmental regulations aimed at their correct disposal. TPO has different characteristics depending on the used raw material conditions and operating conditions in the case of pyrolysis. For this reason, it is necessary to characterize the liquids used mainly for atomization and combustion (TPO and diesel).

The tests were carried out in an experimental bench which had been specifically designed to characterize the atomization process of liquid fuels. The atomized liquid was characterized by an experimental determination of droplet size using the Malvern Spraytec 2007 laser diffraction system, model STP5936.

In order to observe the atomization mechanism of the Y-Jet atomizer shown in Fig. 3, it is necessary to use a visualization mechanism inside it $[70,71]$; thence, for the first prototype, an atomizer was built in polymethyl methacrylate (PMMA); unfortunately, this material reacted with TPO due to the presence of aromatic compounds [72]. Therefore, the PMMA injector was tested only with water where the adherence of liquid on the walls of the mixing chamber was observed, which revealed a high concentration of liquid forming a layer on its walls according to the mechanism shown in Fig. 3. In the spray, there is a low amount of droplets in the central midpoint of the jet cone and a higher density in its outer zones, which can be explained by the atomization mechanism and surface tension acting on the bulk liquid formed on the walls of the atomizer mixing chamber.

The pressures in air and liquid lines have great influence on the tested droplet size behavior. A decrease in droplet size was observed in the point where liquid pressure becomes greater than air pressure. For diesel oil, this sudden decrease in droplet size (inflection point) occurs for higher GLR values if compared to the GLR value of the cross-point of pressures (Fig. 10a) and for $2 \%$ and $10 \%$ blends. This inflection point and the cross-point value of pressures are approximately the same as those of GLR, as shown in Fig. 10b, c.

In general, droplet size and pressure are inversely proportional to the GLR, except for the pressure inversion zone which, in addition, has a more uniform droplet size if compared to the behavior of the surrounding areas. The GLR value where liquid fuel pressure exceeds gas pressure is approximately 0.105 . From this point, there is a sudden decrease in droplet size and the continuous curve behavior tends to increase to lower GLR values.

In Fig. 11, it is possible to observe values higher than approximately 0.115 , and the blends exhibit a greater droplet size behavior for diesel, which soon decreases for the $2 \%$ blend and continues to decrease further for the $10 \%$ TPO blend (Fig. 11).

The droplet size prediction shown in Fig. 12 is largely different than the theoretical value estimated by Wigg's equation due to an irregular behavior of the experimental results at the previously described inflection point (cross-point values of air and fuel lines), while the behavior of Wigg's equation is a regular decreasing curve. Experimentally, it has been observed that the spray behavior at this inflection point, in addition to having a more uniform droplet size, shows a significant noise decrease. 


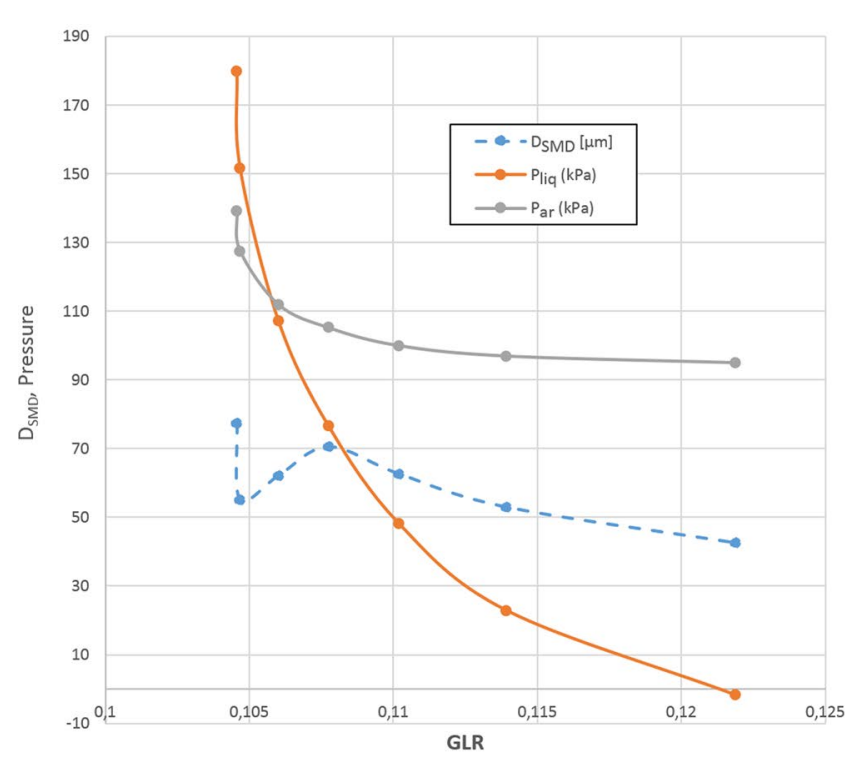

(a)

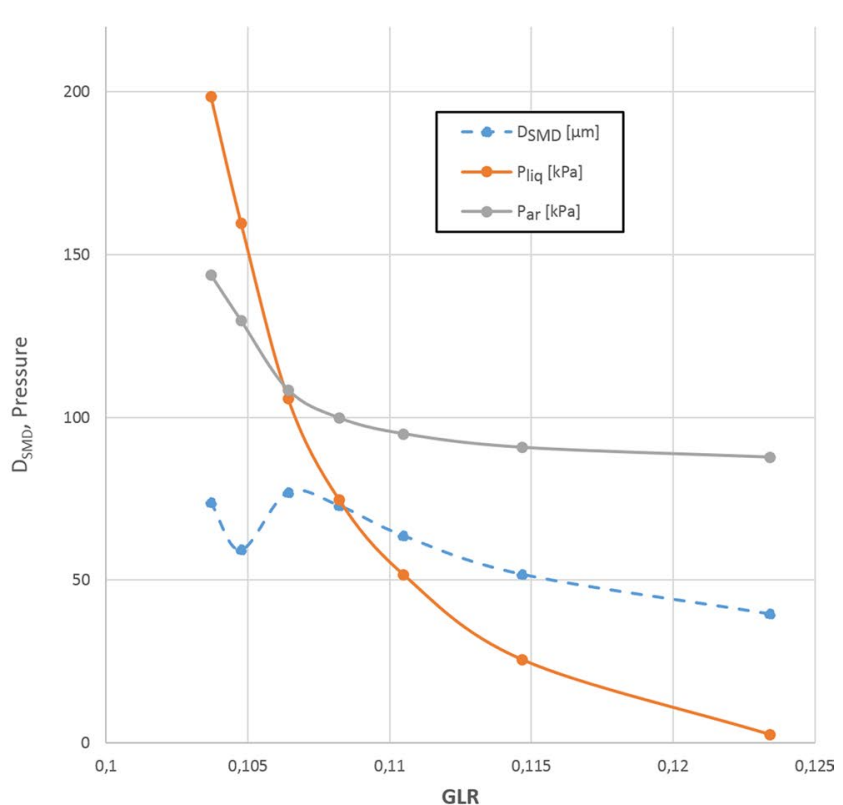

(b)

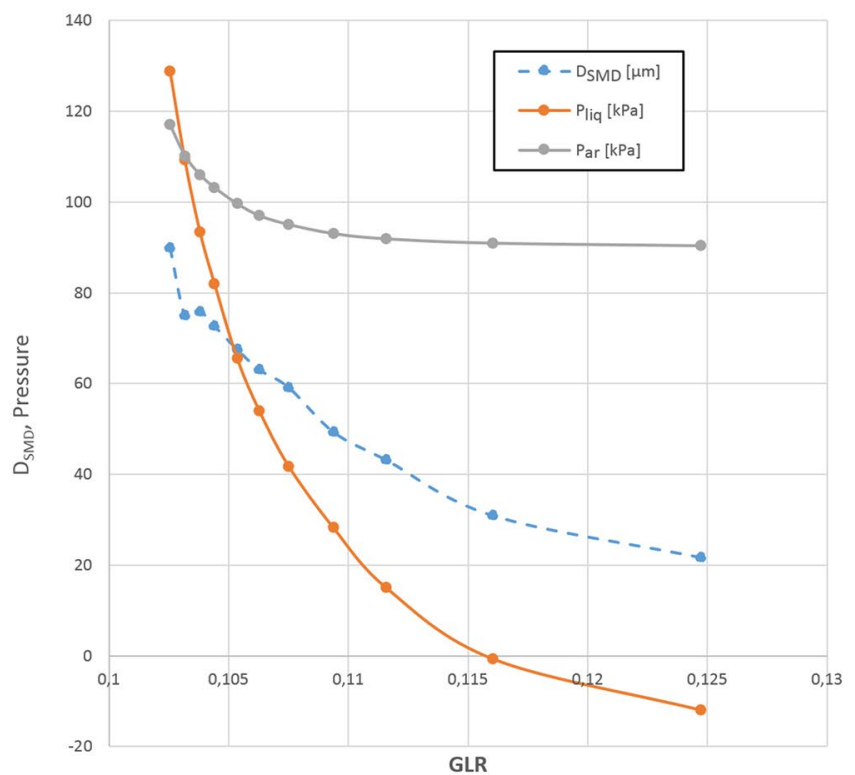

(c)

Fig. 10 Gas and liquid pressures and Y-jet atomizer droplet size: a diesel $4 \mathrm{~L} / \mathrm{min}$ of air b $2 \%$ TPO, $4 \mathrm{~L} / \mathrm{min}$ of air, $\mathbf{c}$ with $10 \%$ TPO, $4 \mathrm{~L} / \mathrm{min}$ of air

Afterward, it is going to be presented as an example calculation for the Y-Jet atomizer sizing.

\subsection{Calculation example of the 35-kW Y-Jet atomizer}

The following shows the calculation that was used to determine $d_{\mathrm{g}}$ and $d_{1}$ (see Fig. 4) and to estimate the droplet diameter $\left(D_{\mathrm{MMD}}\right)$ according to Eq. (5) for the 35-kW Y-Jet atomizer. For this atomizer, the fuel mass flow is calculated as:

$\dot{m}_{1}=\frac{\text { Potência }}{\text { PCI }_{\mathrm{OPPU}}}=\frac{35 \mathrm{~kW}}{39891 \mathrm{~kJ} / \mathrm{kg}}=8.8 \times 10^{-4} \mathrm{~kg} / \mathrm{s}$

The mass flow ratio between the atomizing gas and liquid (GLR) is recommended to be in the range of 0.05-0.15; therefore, the value of 0.15 for the present calculation was selected. 


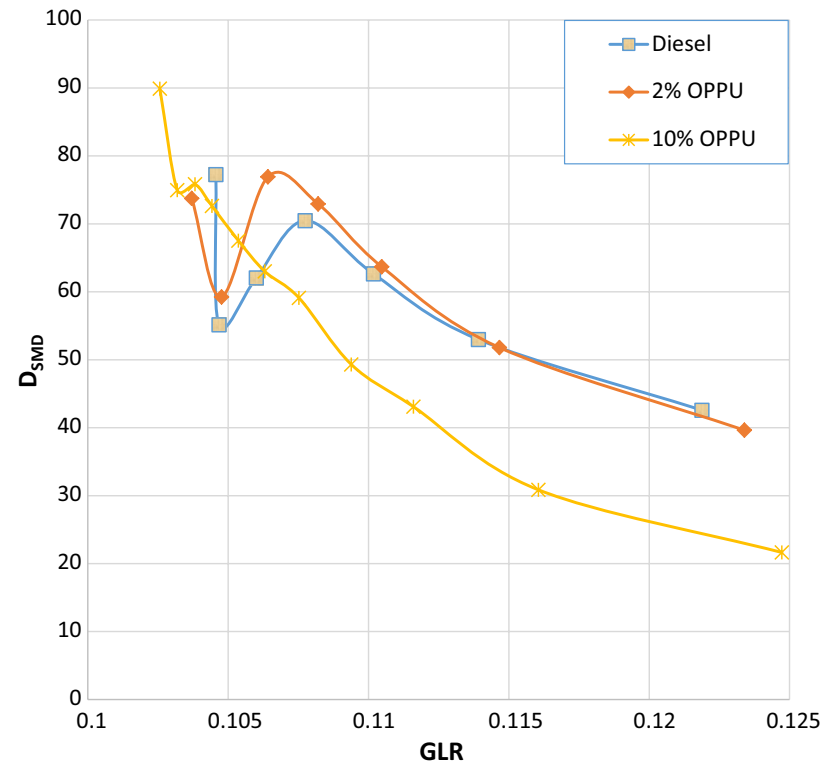

Fig. 11 Comparison of $D_{\mathrm{SMD}}$ droplet size in the Y-Jet atomizer for $2 \%$ TPO, diesel and 10\% TPO (4 L/min air)

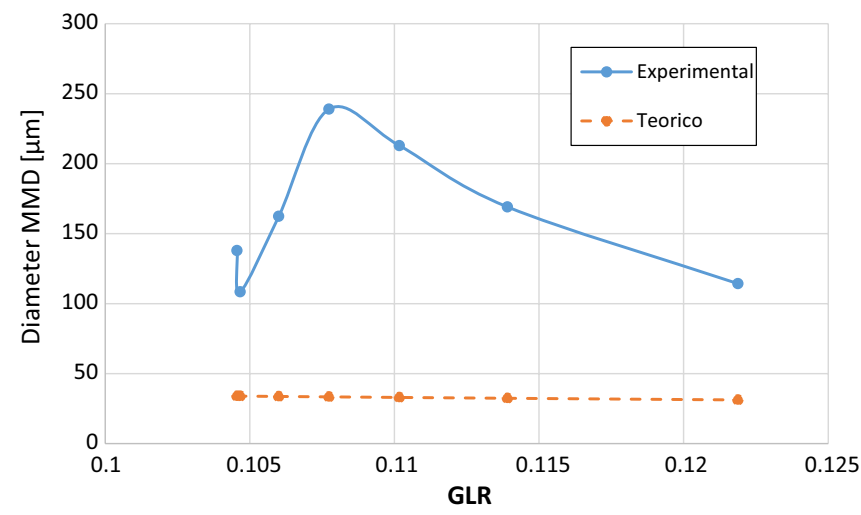

(a)
The maximum value of this range to obtain the highest air and fuel flow to ensure greater dimensions for the atomizer internal ducts was chosen, and thus, the machining to be performed will be simpler. By calculating the $\dot{m}_{g}$ :

$\mathrm{GLR}=\dot{m}_{\mathrm{g}} / \dot{m}_{1}=0.15 \rightarrow \dot{m}_{\mathrm{g}}=0.000132 \mathrm{~kg} / \mathrm{s}$

By using Eqs. (1)-(4), the following parameters are calculated: (7)Air temperature (Eq. 1):

$T^{*}=300 \times\left(\frac{2}{1.4+1}\right)=250 \mathrm{~K}$

Air pressure (Eq. 2):

$p^{*}=300\left(\frac{2}{1+1.4}\right)^{\frac{1.4}{0.4}}=158.48 \mathrm{kPa}$

Air density (Eq. 3):

$\rho^{*}=\frac{158.48}{250 \times 0.287}=2.21 \mathrm{kPa}$

Air speed at the inlet of the mixing chamber (by considering $\mathrm{Ma}=1$ )

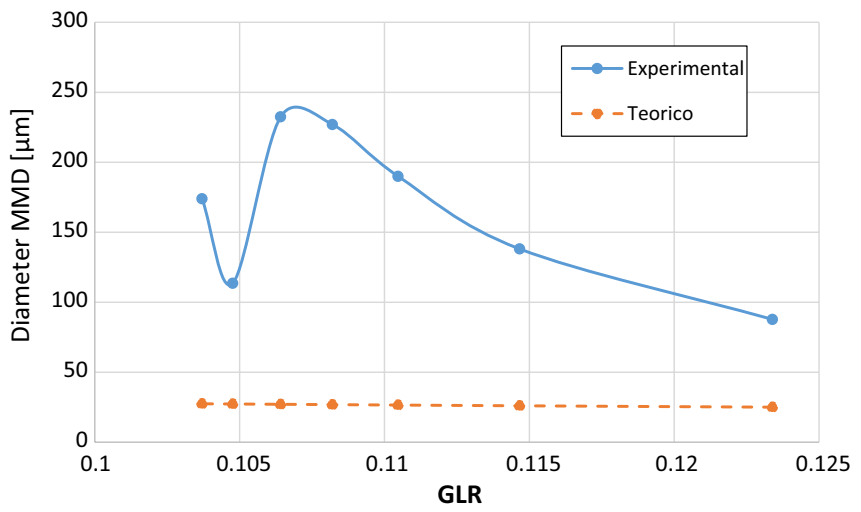

(b)

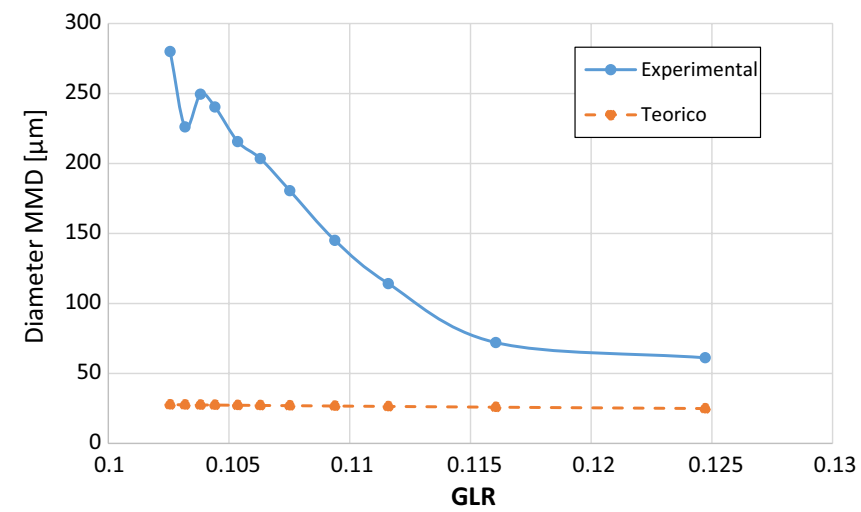

(c)

Fig. 12 Comparison of experimental and theoretical drop size calculated according to Wigg: a diesel, $4 \mathrm{~L} / \mathrm{min}$ of air, b with $2 \%$ TPO, $4 \mathrm{~L} / \mathrm{min}$ air and $\mathbf{c}$ with $10 \% \mathrm{TPO}, 4 \mathrm{~L} / \mathrm{min}$ air 
Fig. 13 Cone angle size for: a with $2 \%$ TPO, GLR $=0.0846$, b with $2 \%$ TPO, GLR $=0.0806$, c with $10 \%$ TPO, GLR $=0.0708$, d with $10 \%$ TPO,

$\mathrm{GLR}=0.0643$, e with diesel, $\mathrm{GLR}=0.0848$, f with diesel, $\mathrm{GLR}=0.0773$

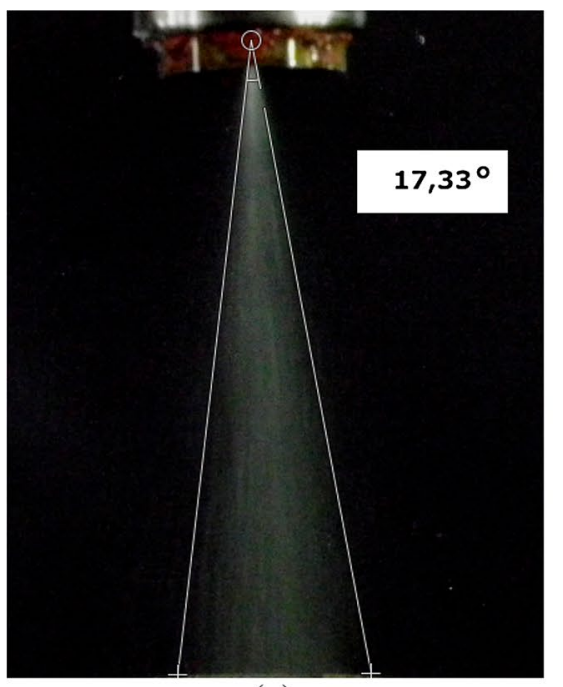

(a)

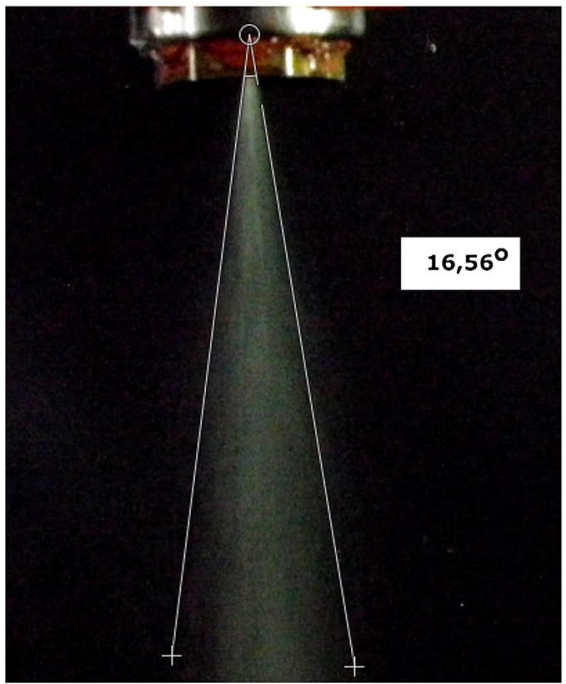

(c)

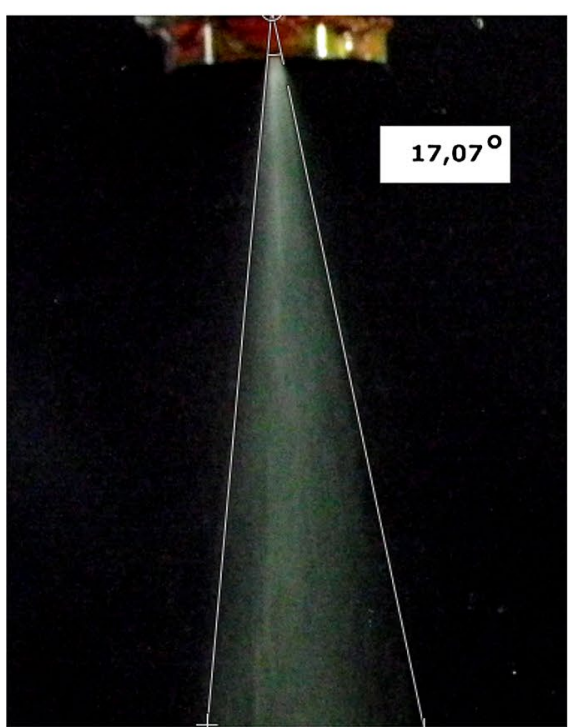

(e)

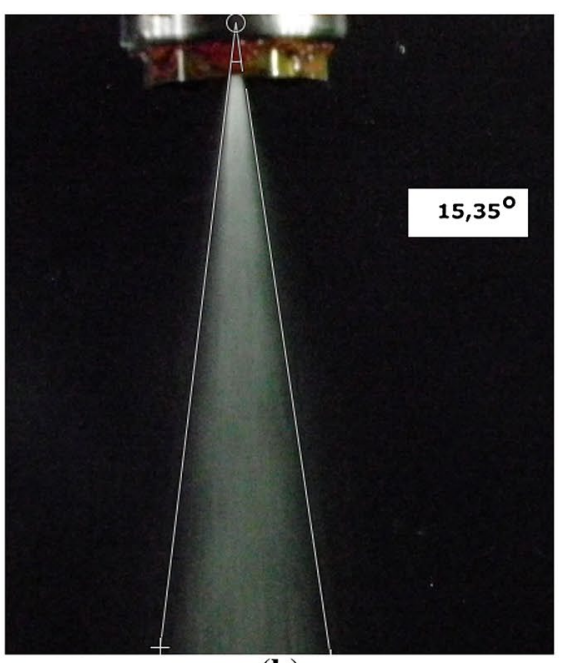

(b)

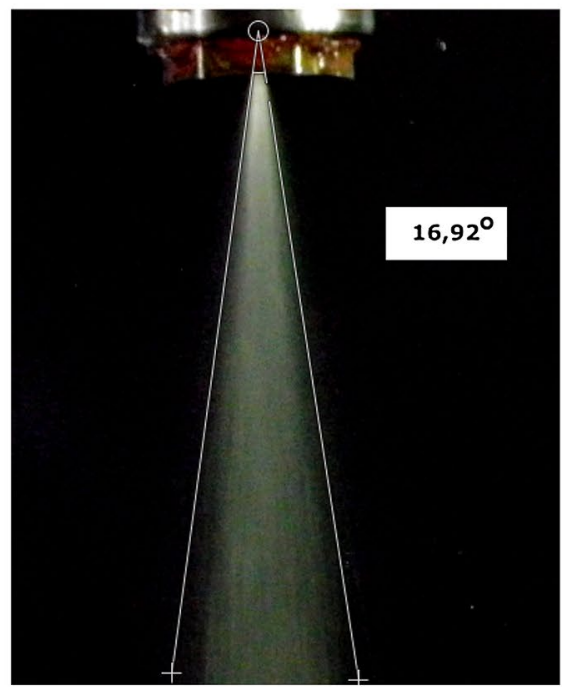

(d)

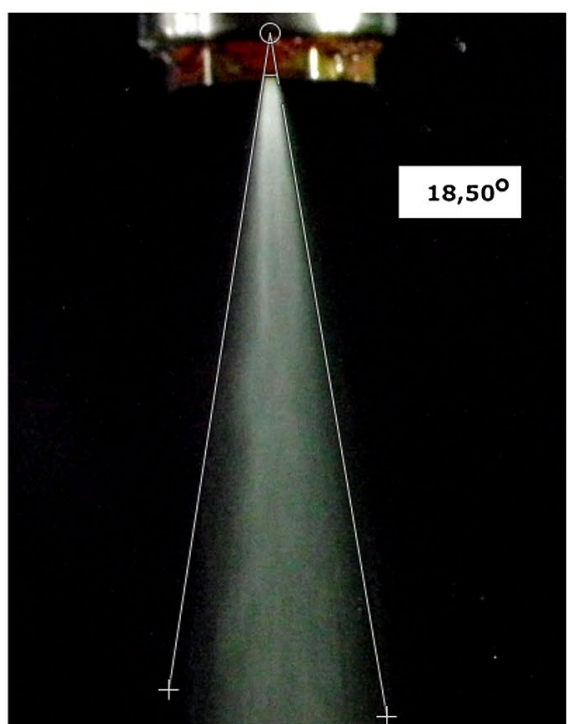

(f) 
$v^{*}=\sqrt{k \times R \times T}$

$v^{*}=\sqrt{1.4 \times 287 \times 250}=316.94 \mathrm{~m} / \mathrm{s}$

Diameter of atomizer nozzle (Eq. 4):

$A_{g}^{*}=1.88 \times 10^{-5} \times \frac{\sqrt{287 \times 250}}{3 \times 10^{5} \sqrt{1.4}}\left(\frac{2}{1.4+1}\right)^{-\frac{1.4+1}{2(1.4-1)}}=1.88 \times 10^{-7} \mathrm{~m}^{2}$

Finally, with this value, the air duct diameter is calculated.

$d_{\mathrm{g}}=\sqrt{4 A / \pi}=\sqrt{\frac{4 \times 1.88 \times 10^{-7}}{\pi}}=4.9 \times 10^{-4} \mathrm{~m}$

From this value, the values in Table 5 are obtained.

On the other hand, to estimate the $D_{\mathrm{MMD}}$, Eq. (5) is used, whose data are as follows:

$$
\begin{aligned}
& v_{L}=5.1532 \mathrm{cSt} \quad \dot{m}_{L}=0.87739 \mathrm{~g} / \mathrm{s} \\
& h=0.044032 \mathrm{~cm} \\
& \sigma=28.091 \mathrm{dyne} / \mathrm{cm} \quad \rho_{A}=0.0022381 \mathrm{~g} / \mathrm{cm}^{3} \\
& U_{A}=316.9384798 \mathrm{~m} / \mathrm{s} \\
& D_{\mathrm{MMD}} \\
& \quad=\frac{200 \times 5.1532^{0.5} \times 0.87739^{0.1}(1+1 / 0.15)^{0.5} \times 0.044032^{0.1} 28.091^{0.2}}{0.0022381^{0.3} \times 316.9384798} \\
& \quad=34.82 \mu \mathrm{m}
\end{aligned}
$$

Acknowledgements Funding for this study was provided by the Fundação de Amparo à Pesquisa do Estado de Minas Gerais, FAPEMIG-Brazil PEMIG (Proc. No. TEC-APQ-01947-14), CAPES-Brazil and CNPq-Brazil (Proc. Nos. 442050/2014-3 and 305965/2016-6).

\section{References}

1. Instituto Brasileiro do Meio Ambiente e dos Recursos Naturais Renováveis. Relatório Pneumáticos 2017. Brasília: 2017

2. JATMA. Tyre Industry. 2017

3. Williams PT, Bottrill RP, Cunliffe AM (1998) Combustion of tyre pyrolysis oil. Process Saf Environ Prot 76:291-301. https://doi. org/10.1205/095758298529650

4. Murugan S, Ramaswamy MC, Nagarajan G (2008) A comparative study on the performance, emission and combustion studies of a DI diesel engine using distilled tyre pyrolysis oil-diesel blends. Fuel 87:2111-2121. https://doi.org/10.1016/j.fuel.2008.01.008

5. Murugan S, Ramaswamy MC, Nagarajan G (2008) The use of tyre pyrolysis oil in diesel engines. Waste Manag 28:2743-2749. https ://doi.org/10.1016/j.wasman.2008.03.007

6. Murugan S, Ramaswamy C, Nagarajan G (2008) Influence of distillation on performance, emission, and combustion of a DI diesel engine, using tyre pyrolysis oil diesel blends. Therm Sci 12:157-167. https://doi.org/10.2298/TSCI0801157M

7. Murugan S, Ramaswamy MC, Nagarajan G (2008) Performance, emission and combustion studies of a DI diesel engine using distilled tyre pyrolysis oil-diesel blends. Fuel Process Technol 89:152-159. https://doi.org/10.1016/j.fuproc.2007.08.005

8. Martínez JD, Lapuerta M, García-Contreras R, Murillo R, García $T$ (2013) Fuel properties of tire pyrolysis liquid and its blends with diesel fuel. Energy Fuels 27:3296-3305. https://doi.org/10.1021/ ef400602e

9. Sharma A, Murugan S (2013) Investigation on the behaviour of a DI diesel engine fueled with Jatropha methyl ester (JME) and tyre pyrolysis oil (TPO) blends. Fuel 108:699-708. https://doi. org/10.1016/j.fuel.2012.12.042

10. Sharma A, Murugan S (2014) Influence of fuel injection timing on the performance and emission characteristics of a diesel engine fueled with Jatropha methyl ester-tyre pyrolysis oil blend. Appl Mech Mater 592-594:1627-1631. https://doi.org/10.4028/www. scientific.net/AMM.592-594.1627

11. Martínez JD, Rodríguez-Fernández J, Sánchez-Valdepeñas J, Murillo R, García T (2014) Performance and emissions of an automotive diesel engine using a tire pyrolysis liquid blend. Fuel 115:490-499. https://doi.org/10.1016/j.fuel.2013.07.051

12. Koc AB, Abdullah M (2014) Performance of a 4-cylinder diesel engine running on tire oil-biodiesel-diesel blend. Fuel Process Technol 118:264-269. https://doi.org/10.1016/j.fupro c. 2013.09.013

13. Ballesteros R, Guillén-Flores J, Martínez JD (2014) Carbonyl emission and toxicity profile of diesel blends with an animal-fat biodiesel and a tire pyrolysis liquid fuel. Chemosphere 96:155166. https://doi.org/10.1016/j.chemosphere.2013.10.017

14. García-Contreras R, Martínez JD, Armas O, Murillo R, García T (2015) Study of a residential boiler under start-transient conditions using a tire pyrolysis liquid (TPL)/diesel fuel blend. Fuel 158:744-752. https://doi.org/10.1016/j.fuel.2015.06.046

15. Sharma A, Murugan S (2015) Potential for using a tyre pyrolysis oil-biodiesel blend in a diesel engine at different compression ratios. Energy Convers Manag 93:289-297. https://doi. org/10.1016/j.enconman.2015.01.023

16. Sharma A, Murugan S (2016) Experimental evaluation of combustion parameters of a DI diesel engine operating with biodiesel blend at varying injection timings. In: Kumar S, Khanal S, Yadav $\mathrm{Y}$ (eds) Proceedings of first international conference on recent advances bioenergy research, New Delhi. Springer, Berlin pp 169-77. https://doi.org/10.1007/978-81-322-2773-1_13

17. Wang WC, Bai CJ, Lin CT, Prakash S (2016) Alternative fuel produced from thermal pyrolysis of waste tires and its use in a DI diesel engine. Appl Therm Eng 93:330-338. https://doi. org/10.1016/j.applthermaleng.2015.09.056

18. Pilusa TJ (2017) The use of modified tyre derived fuel for compression ignition engines. Waste Manag 60:451-459. https://doi. org/10.1016/j.wasman.2016.06.020

19. Hürdoğan E, Ozalp C, Kara O, Ozcanli M (2017) Experimental investigation on performance and emission characteristics of waste tire pyrolysis oil-diesel blends in a diesel engine. Int J Hydrogen Energy 42:23373-23378. https://doi.org/10.1016/j. ijhydene.2016.12.126

20. Vihar R, Žvar Baškovič U, Seljak T, Katrašnik T (2017) Combustion and emission formation phenomena of tire pyrolysis oil in a common rail Diesel engine. Energy Convers Manag 149:706-721. https://doi.org/10.1016/j.enconman.2017.02.005

21. Sharma A, Murugan S (2017) Effect of blending waste tyre derived fuel on oxidation stability of biodiesel and performance and emission studies of a diesel engine. Appl Therm Eng 118:365-374. https://doi.org/10.1016/j.applthermaleng.2017.03.008

22. Martínez JD, Lapuerta M, García-Contreras R, Murillo R, García $\mathrm{T}$ (2013) fuel properties of tire pyrolysis liquid and its blends with diesel fuel. Energy Fuels 27:3296-3305. https://doi.org/10.1021/ ef $400602 \mathrm{e}$ 
23. Sharma VK, Fortuna F, Mincarini M, Berillo M, Cornacchia G (2000) Disposal of waste tyres for energy recovery and safe environment. Appl Energy 65:381-394. https://doi.org/10.1016/ S0306-2619(99)00085-9

24. Williams PT (2013) Pyrolysis of waste tyres: a review. Waste Manag 33:1714-1728. https://doi.org/10.1016/j.wasma n.2013.05.003

25. ANIP. Dados de produção 2016:1-2. http://www.anip.com.br/ arquivos/producao-vendas.pdf. Accessed 16 Apr 2018

26. Nieto-Márquez A, Atanes E, Morena J, Fernández-Martínez F, Valverde JL (2016) Upgrading waste tires by chemical activation for the capture of $\mathrm{SO}_{2}$. Fuel Process Technol 144:274-281. https://doi.org/10.1016/j.fuproc.2016.01.009

27. Al-Lal AM, Bolonio D, Llamas A, Lapuerta M, Canoira L (2015) Desulfurization of pyrolysis fuels obtained from waste: lube oils, tires and plastics. Fuel 150:208-216. https://doi. org/10.1016/j.fuel.2015.02.034

28. Araújo Costa F, Silva RJ (2005) Pneus inservíveis: análise das leis ambientais vigentes e processos de destinação final adequados. XXV Encontro Nac. Eng. Produção, Porto Alegre, pp $5227-5234$

29. Jantaraksa N, Prasassarakich P, Reubroycharoen P, Hinchiranan N (2015) Cleaner alternative liquid fuels derived from the hydrodesulfurization of waste tire pyrolysis oil. Energy Convers Manag 95:424-434. https://doi.org/10.1016/j.enconman.2015.02.003

30. ETRMA. End of life tyres-A valuable resource with growing potential 2011:1-22. http://www.etrma.org/uploads/Modules/ Documentsmanager/brochure-elt-2011-final.pdf Accessed 3 July 2016

31. ANIP. Reciclanip. Legislação n.d. http://www.reciclanip.org.br/ v3/legislacao

32. SAC PETROBRAS. Unidade de Industrialização do Xisto (SIX): Operações I Petrobras. Unidade Ind Do Xisto n.d. http://www. petrobras.com.br/pt/nossas-atividades/principais-operacoes/refin arias/unidade-de-industrializacao-do-xisto-six.htm. Accessed 7 Dec 2016

33. IBAMA. Relatório de Pneumáticos Resolução CONAMA no 416/09. 2015. https://doi.org/10.1017/cbo9781107415324.004

34. Martínez JD, Puy N, Murillo R, García T, Navarro MV, Mastral AM (2013) Waste tyre pyrolysis - a review. Renew Sustain Energy Rev 23:179-213. https://doi.org/10.1016/j.rser.2013.02.038

35. Leung DYC, Yin XL, Zhao ZL, Xu BY, Chen Y (2002) Pyrolysis of tire powder: influence of operation variables on the composition and yields of gaseous product. Fuel Process Technol 79:141155. https://doi.org/10.1016/S0378-3820(02)00109-1

36. Nsaful F, Görgens JF, Knoetze JH (2013) Comparison of combustion and pyrolysis for energy generation in a sugarcane mill. Energy Convers Manag 74:524-534. https://doi.org/10.1016/j. enconman.2013.07.024

37. Sallevelt JLHP, Pozarlik AK, Brem G (2016) Numerical study of pyrolysis oil combustion in an industrial gas turbine. Energy Convers Manag 127:504-514. https://doi.org/10.1016/j.encon man.2016.09.029

38. Harker JH, Backhurst JR (1981) Fuel and energy. Academic Press, Cambridge

39. Siva M, Onenc S, Uçar S, Yanik J (2013) Influence of oily wastes on the pyrolysis of scrap tire. Energy Convers Manag 75:474-481. https://doi.org/10.1016/j.enconman.2013.06.055

40. Undri A, Meini S, Rosi L, Frediani M, Frediani P (2013) Microwave pyrolysis of polymeric materials: waste tires treatment and characterization of the value-added products. J Anal Appl Pyrolysis 103:149-158. https://doi.org/10.1016/j.jaap.2012.11.011

41. Roy C, Chaala A, Darmstadt H (1999) Vacuum pyrolysis of used tires end-uses for oil and carbon black products. J Anal Appl Pyrolysis 51:201-221. https://doi.org/10.1016/S0165 $-2370(99) 00017-0$
42. Galvagno S, Casu S, Casabianca T, Calabrese A, Cornacchia G (2002) Pyrolysis process for the treatment of scrap tyres: preliminary experimental results. Waste Manag 22:917-923. https://doi. org/10.1016/S0956-053X(02)00083-1

43. Li S-Q, Yao Q, Chi Y, Yan J-H, Cen K-F (2004) Pilot-scale pyrolysis of scrap tires in a continuous rotary kiln reactor. Ind Eng Chem Res 43:5133-5145. https://doi.org/10.1021/ie030115m

44. Islam MR, Haniu H, Beg MRA (2008) Liquid fuels and chemicals from pyrolysis of motorcycle tire waste: product yields, compositions and related properties. Fuel 87:3112-3122. https://doi. org/10.1016/j.fuel.2008.04.036

45. Murugan S, Ramaswamy MC, Nagarajan G (2009) Assessment of pyrolysis oil as an energy source for diesel engines. Fuel Process Technol 90:67-74. https://doi.org/10.1016/j.fuproc.2008.07.017

46. Aydin H, Ilkiliç C (2012) Optimization of fuel production from waste vehicle tires by pyrolysis and resembling to diesel fuel by various desulfurization methods. Fuel 102:605-612. https://doi. org/10.1016/j.fuel.2012.06.067

47. Banar M, Akyildiz V, Özkan A, Çokaygil Z, Onay Ö (2012) Characterization of pyrolytic oil obtained from pyrolysis of TDF (Tire Derived Fuel). Energy Convers Manag 62:22-30. https://doi. org/10.1016/j.enconman.2012.03.019

48. Quispe Gonzales CA, Costa F de S, Carvalho Jr JA de. Análise do escoamento em regime subsônico e influência no diâmetro médio das gotas para Injetores de mistura interna tipo Y. $10^{\circ}$ Congr. Iberoam. Eng. Mecânica, Porto: 2011

49. Beér JM, Chigier NA (1972) Combustion aerodynamics. Applied Science Publishers, London

50. Petela R (1982) Analyses of atomization processes. Fuel 61:11351137. https://doi.org/10.1016/0016-2361(82)90199-5

51. Suh HK, Park SH, Kim HJ, Lee CS (2009) Influence of ambient flow conditions on the droplet atomization characteristics of dimethyl ether (DME). Fuel 88:1070-1077. https://doi.org/10.1016/j. fuel.2008.11.018

52. Tsai SC, Viers B (1990) Airblast atomization of viscous liquids. Fuel 69:1412-1419. https://doi.org/10.1016/0016-2361(90)90123 $-8$

53. Tsai SC, Ghazimorad K, Viers B (1991) Airblast atomization of micronized coal slurries using a twin-fluid jet atomizer. Fuel 70:483-490. https://doi.org/10.1016/0016-2361(91)90025-6

54. Azevedo Gonçalves C. Desenvolvimento de um sistema compacto de combustão sem chama visível utilizando um injetor blurry para queima de biocombustíveis. Instituto Nacional de Pesquisas Espaciais, 2013

55. Lefebvre AH (1989) Atomization and sprays. Taylor \& Francis, Routledge

56. Broukal J, Hájek J (2011) Validation of an effervescent spray model with secondary atomization and its application to modeling of a large-scale furnace. Appl Therm Eng 31:2153-2164. https:// doi.org/10.1016/j.applthermaleng.2011.04.025

57. Cui J, Lai H, Li J, Ma Y (2017) Visualization of internal flow and the effect of orifice geometry on the characteristics of spray and flow field in pressure-swirl atomizers. Appl Therm Eng 127:812822. https://doi.org/10.1016/j.applthermaleng.2017.08.103

58. Zhou Y, Zhang M, Yu J, Zhu X, Peng J (2010) Experimental investigation and model improvement on the atomization performance of single-hole Y-jet nozzle with high liquid flow rate. Powder Technol 199:248-255. https://doi.org/10.1016/j.powte c. 2010.01 .013

59. Lacava PT, Pimenta AP, de Carvalho Jr JA (2004) Atomizador tipo "Y-jet"-Projeto, características do spray e combustão. Proc. $10^{\circ}$ Brazilian Congr. Therm. Sci. Eng.-ENCIT 2004, Rio de Janeiro, p 11

60. Zeng K, Minh DP, Gauthier D, Weiss-Hortala E, Nzihou A, Flamant G (2015) The effect of temperature and heating rate on char properties obtained from solar pyrolysis of beech wood. 
Bioresour Technol 182:114-119. https://doi.org/10.1016/j.biort ech.2015.01.112

61. Li Z, Wu Y, Yang H, Cai C, Zhang H, Hashiguchi K et al (2013) Effect of liquid viscosity on atomization in an internal-mixing twin-fluid atomizer. Fuel 103:486-494. https://doi.org/10.1016/j. fuel.2012.06.097

62. Ejim CE, Rahman MA, Amirfazli A, Fleck BA (2010) Effects of liquid viscosity and surface tension on atomization in two-phase, gas/liquid fluid coker nozzles. Fuel 89:1872-1882. https://doi. org/10.1016/j.fuel.2010.03.005

63. Watanabe H, Suwa Y, Matsushita Y, Morozumi Y, Aoki H, Tanno $S$ et al (2007) Spray combustion simulation including soot and NO formation. Energy Convers Manag 48:2077-2089. https://doi. org/10.1016/j.enconman.2007.01.008

64. Watanabe H, Suwa Y, Matsushita Y, Morozumi Y, Aoki H, Tanno S et al (2008) Numerical investigation of spray combustion in jet mixing type combustor for low NOx emission. Energy Convers Manag 49:1530-1537. https://doi.org/10.1016/j.encon man.2007.12.002

65. Mullinger PJ, Chigier NA (1974) The design and performance of internal mixing multijet twin fluid atomizers. J Inst Fuel 47:251-261

66. Quispe Gonzales CA (2013) Investigação de injetores tipo Y e efervescentes para a atomização da mistura de glicerina e etanol. UNESP- FEG
67. Lacava PT, Carvalho Jr JA, Mcquay MQ. Metodologia para el diseño de atomizadores tipo "Y." Inf Tecnológica 1998;9

68. Apaza Vásquez R (2011) Desenvolvimento De Um Injetor Centrífugo Dual Para Biocombustíveis Líquidos. Instituto Nacional de Pesquisas Espaciais-INPE

69. Spraytec M. Spraytec User Manual 2006:216. http://www.malve rn.com/en/support/resource-center/user-manuals/MAN0368EN. aspx. Accessed 7 Mar 2017

70. Jiang G, Zhang Y, Wen H, Xiao G (2015) Study of the generated density of cavitation inside diesel nozzle using different fuels and nozzles. Energy Convers Manag 103:208-217. https://doi. org/10.1016/j.enconman.2015.06.065

71. Song SH, Lee SY (1996) Study of atomization mechanism of gas/liquid mixtures flowing through y-jet atomizers. At Sprays 6:193-209

72. António NN (2007) Estudo dos mecanismos de despolimerização térmica do Poli(metacrilato de metilo), escolha de solventes compatíveis com PMMA. Instituto Superior Técnico Universidade Técnica de Lisboa

Publisher's Note Springer Nature remains neutral with regard to jurisdictional claims in published maps and institutional affiliations. 